$A 11107$ 2599927

U.S. DEPARTMENT OF COMMERCE

National Institute of Standards and Technology

(formerlv National Bureau of Standards)

NIST

PUBLICATIONS

NIST Special Publication 753

\title{
Data Bases Available at the National Institute of Standards and Technology Research Information Center
}

\section{Diane Cunningham}

AGRICOLA(National Agricultural Library)

CANCERL IT (National Library of Medicine)

CENDATA (Bureau of the Census)

DOE ENERGY(Department of Energy)

FEDERAL APPLIED TECHNOLOGY DATABASE (NTIS)

FEDERAL RESEARCH IN PROGRESS(NTIS)

GPO MONTHLY CATALOG(Government Printing Office)

MEDLINE(National Library of Medicine)

NTIS(National Technical Information Service)

NUCLEAR SCIENCE ABSTRACTS(DOE)

OCCUPATIONAL SAFETY \& HEALTH(NIOSH)

SMOKING AND HEALTH(HHS)

TRIS(Department of Transportation)

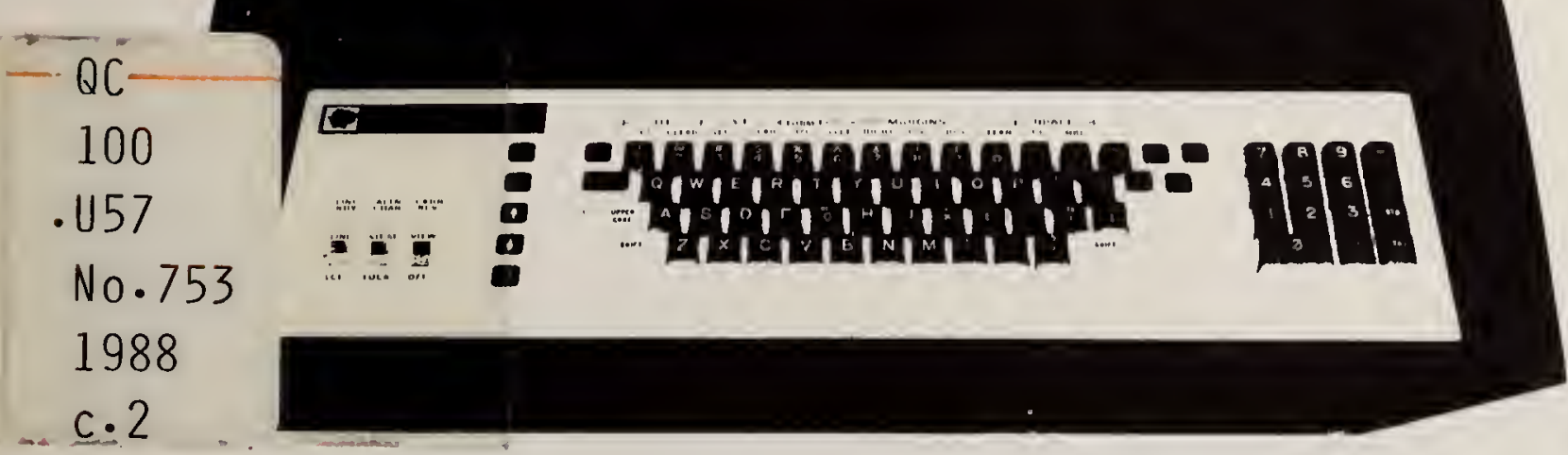


NATIONAL DNSTINUTE OF STANDARDS \&

TWCHNOLOG

Research Information Center

Gaithersburg, MD 20899 


\section{NIST Special Publication 753}

\section{Data Bases Available at the National Institute of Standards and Technology Research Information Center}

Diane Cunningham

Information Resources and Services Division National Institute of Standards and Technology (formerly National Bureau of Standards)

Gaithersburg, MD 20899

Supersedes NBSIR 87-3658 (July 1987)

November 1988

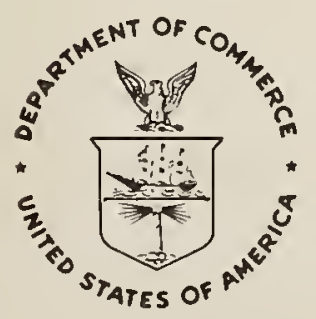

NOTE: As of 23 August 1988, The National Bureau of Standards (NBS) became the National Institute of Standards and Technology (NIST) when President Reagan signed into law the Omnibus Trade and Competitiveness Act.

U.S. Department of Commerce

C. William Verity, Secretary

National Institute of Standards and Technology (formerly National Bureau of Standards)

Ernest Ambler, Director 
Library of Congress

Catalog Card Number: 88-600602

National Institute of Standards

and Technology

Special Publication 753

Natl. Inst. Stand. Technol.

Spec. Publ. 753

114 pages (Nov. 1988)

CODEN: NSPUE2
U.S. Government Printing Office

Washington: 1988

For sale by the Superintendent of Documents

U.S. Government Printing Office Washington, DC 20402 


\section{PREFACE}

This Publication supersedes and revises NBSIR 87-3658, which is dated July 1987.

Data bases are listed by acronyms and by full titles. Citations also include data base dates of coverage, brief descriptions, kinds of information each contains, producers, the titles of corresponding hard copy, and vendors. A list of vendors with addresses and telephone numbers precedes the list.

The General Subject Index is arranged alphabetically by subject categories and the Cross Reference Index lists variant forms of the names of the data bases in the left column with cross references to the name of the data base used in this Publication on the right.

If you are an NIST employee or an NIST associate and are interested in a literature search, call extension 3052 or see an Information Specialist. For additions or changes that have occurred since the publication of this Report, please contact an Information Specialist.

I wish to thank Karen Jones for her able assistance and diligence in preparing this Publication.

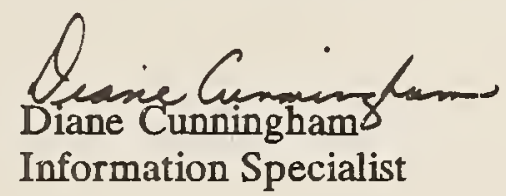





\section{CONTENTS}

Preface.$\ldots \ldots \ldots \ldots \ldots \ldots \ldots \ldots \ldots \ldots \ldots \ldots \ldots \ldots \ldots \ldots \ldots \ldots$ iii

Vendors $\ldots \ldots \ldots \ldots \ldots \ldots \ldots \ldots \ldots \ldots \ldots \ldots \ldots \ldots \ldots \ldots \ldots \ldots \ldots$ vii

List of Data Bases $\ldots \ldots \ldots \ldots \ldots \ldots \ldots \ldots \ldots \ldots \ldots \ldots \ldots \ldots \ldots$

General Subject Index........................ 78

Cross Reference Index ....................... 102 



\section{VENDORS}

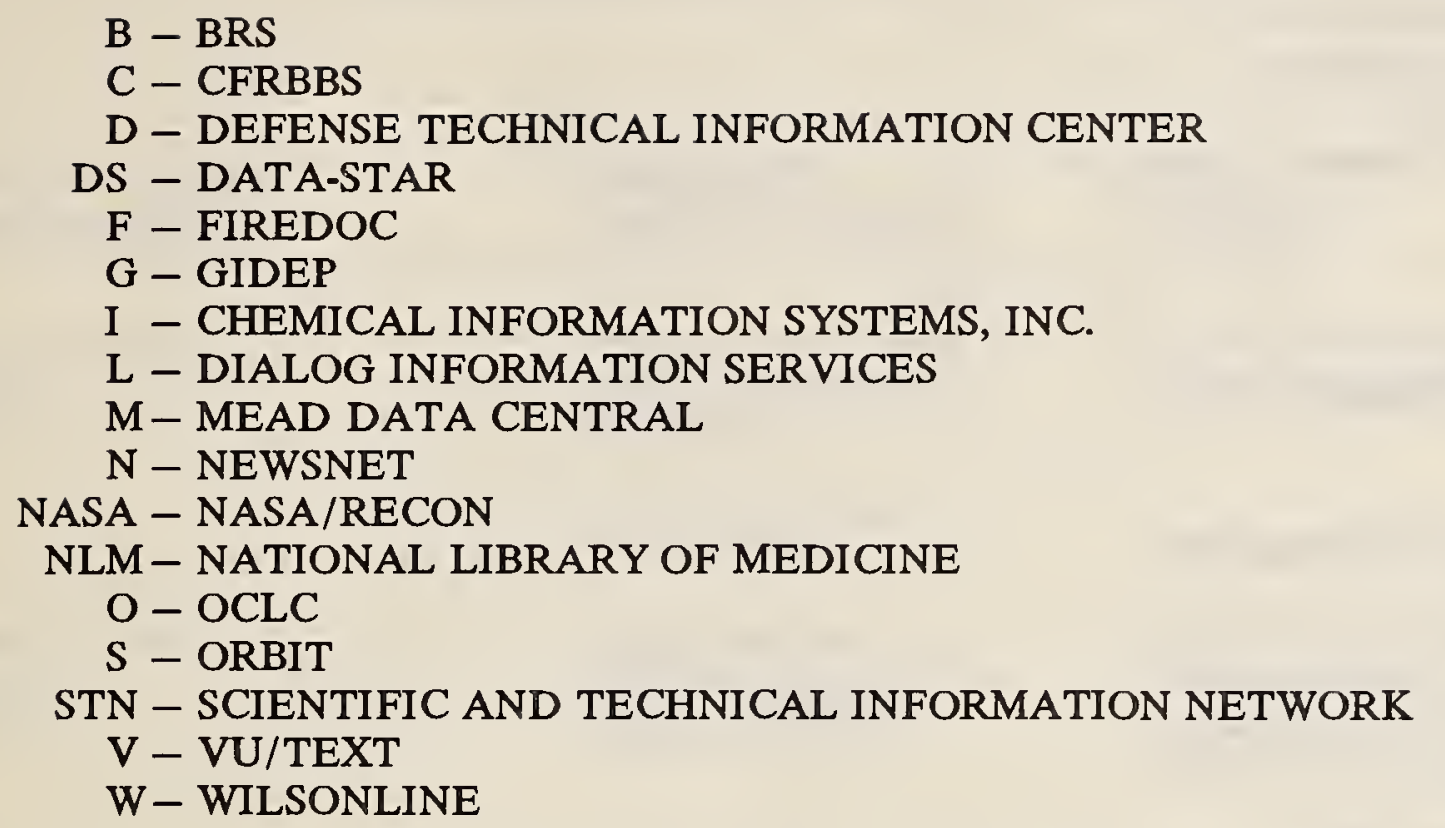

BRS-BRS Information Technologies 1200 Route 7

Latham, New York 12110

(800) 345-4BRS

\section{C-CFRBBS}

Doug Walton

Center for Fire Research

National Institute of Standards and Technology

B345 Polymer Bldg.

Gaithersburg, Maryland 20899

(301) $975-6872$

D-Defense Technical Information Center

Department of Defense

Bldg. 5 Cameron Station

Alexandria, Virginia 22304-6145

(202) 274-6871

DS-DATA-STAR

D-S Marketing, Incorporated

Suite 110

485 Devon Park Drive

Wayne, Pennsylvania 19087

(800) 221-7754

F-FIREDOC

Nora Jason

Fire Research Information Service

Center for Fire Research

National Institute of Standards and Technology

A252 Polymer Bldg.

Gaithersburg, Maryland 20899

(301) $975-6862$
GIDEP - GIDEP Operations Center

Corona, California 91720

(714) $736-4677$

I-Chemical Information Systems, Incorporated 7215 York Road

Baltimore, Maryland 21212

(301) 321-8440

L-DIALOG Information Services, Incorporated 3460 Hillview Avenue

Palo Alto, California 94304

(800) 334-2564

M-Mead Data Center

The Mead Corporation

9443 Springboro Pike

P.O. Box 933

Dayton, Ohio 45401

(800) $227-4908$

N--NEWSNET Incorporated

945 Haverford Road

Bryn Mawr, Pennsylvania 19010

(800) 345-1301

\author{
NASA - NASA/RECON \\ NASA Scientific and Technical Information \\ Branch \\ Washington, D.C. 20546 \\ (202) 453-2017
}




\section{VENDORS}

NLM - MEDLARS Management Section

National Library of Medicine

Bldg. 38A, Rm. 4N421

Bethesda, Maryland 20894

(301) 496-6193

OCLC-OCLC

6565 Frantz Road

Dublin, Ohio 43017-0702

(614) 764-6000

S-Pergamon Orbit InfoLine, Incorporated

8000 West Park Drive

McLean, Virginia 22102

(800) 421-7229

STN-STN International

2540 Olentangy River Road

P.O. Box 02228

Columbus, Ohio 43202

(614) 421-3600

V-VU/TEXT Information Services, Incorporated 325 Chestnut Street, Suite 1300

Philadelphia, Pennsylvania 19106

(800) 258-8080

W-The H. W. Wilson Company

950 University Avenue

Bronx, New York 10452-9978

(800) 367-6770 


\section{DATA BASES AVAILABLE AT THE NATIONAL INSTITUTE OF STANDARDS AND TECHNOLOGY RESEARCH INFORMATION CENTER}

\section{DATA BASE/DATE OF COVERAGE}

\section{A-V ONLINE}

1964

\author{
DESCRIPTION/ \\ PRINCIPAL SOURCES
}

Nonprint media covering all levels of education and

instruction/

Audiovisual materials
PRODUCER/
HARD COPY

VENDOR

National Information Center
L for Educational Media (NICEM)
Detailed information on 149,000 companies in 32 European countries/
$A B C$ der Deutschen Wirtschaft

DS

ABC EUROPE

Current
Verlags-gesellschaft mbH and Europe Export Edition $\mathrm{GmbH}$ (West Germany)

\section{ABC WEST GERMANY}

Current
Detailed information on 76,000 German companies and their products/
$A B C$ der Deutschen Wirtschaft

DS

(West Germany)

\section{ABI/INFORM \\ 1971-}

Literature on all phases of business management and administration including accounting, data processing, finance, marketing, and production/

Journals

\section{ABLEDATA}

Current
Information on rehabilitation products for the disabled/
National Rehabilitation

B

University of America

B, DS, L, S

Rehabilitation aids

Citations to papers on various topics in economics/
Cambridge University Press

B

\section{ABSTRACTS OF WORKIN
PAPERS IN ECONOMICS} 1982-
Papers issued by prominent economic research organizations

\section{ACADEMIC AMERICAN ENCYCLOPEDIA 1980-}

Full text coverage of a multidisciplinary encyclopedia/
Grolier Electronic Pub., Incorporated
B, DS, L

Encyclopedia 
DATA BASE/ DATE OF COVERAGE

ACCOUNTANTS

1974-
DESCRIPTION/

PRINCIPAL SOURCES
PRODUCER/

HARD COPY
VENDOR

American Institute of Certified $S$

Public Accountants

ACCOUNTANTS' INDEX
Books, speeches, pamphlets, government documents, journals

AEROSPACE DATABASE

1962-

Worldwide literature related to aerospace information/

Journals, proceedings, books, theses, reports
American Institute of Aero-

L nautics and Astronautics (AIAA),

National Aeronautics and Space

Administration (NASA)

INTERNATIONAL AEROSPACE

ABSTRACTS, SCIENTIFIC AND

TECHNICAL AEROSPACE

REPORTS

\section{AGELINE DATABASE}

1978-
Information on services provided to older persons and services rendered by them/

Journals, books, reports, proceedings, theses
American Association of Retired Persons (AARP)

Worldwide patents related to

Chemical Abstracts Service

STN

AGPA

agriculture and pest control/

Patents

Information on the business

aspects of agriculture/

Journals, reports
1985-

AGRIBUSINESS U.S.A.
Worldwide literature in agriculture and related areas/

ON-LINE ACCESS)

1970-
U.S. Dept. of Agriculture, B, L Technical Information Systems, Science and Education Administration

BIBLIOGRAPHY OF AGRICULTURE
Journals, monographs, pamphlets, reports, proceedings, translations
Pioneer Hi-Bred International,

L
Incorporated 
DATA BASE/ DATE

OF COVERAGE
DESCRIPTION/

PRINCIPAL SOURCES
PRODUCER/

HARD COPY

\section{AGRIS INTERNATIONAL \\ 1975-}

Worldwide literature on agriculture with emphasis on the U.S./

Journals, books, reports, proceedings
Food and Agriculture

Organization (FAO)/

United Nations

AGRINDEX
L

DS, L

Royal Society of Chemistry

(U.K.)

\section{3-}

Factual data on pesticides such as physical and chemical properties, uses, applications and toxicities/

Data
Literature on the medical research aspects of AIDS/

Proceedings, reports, books, journals
Bureau of Hygiene and

T. DS
Full text file covering all aspects of AIDS

\section{AIDS KNOWLEDGE BASE 1986-}

Literature coverage of vocational and technical education, manpower economics, employment, etc./

\author{
AIM/ARM (ABSTRACTS OF \\ INSTRUCTIONAL AND \\ RESEARCH MATERIALS) \\ 1967-1976
}

The Center for Vocational Education, Obio State Univeristy
Instructional materials

\section{ABSTRACTS OF INSTRUC- TIONAL MATERIALS IN VOCATIONAL AND TECH- NICAL EDUCATION}

ALCOHOL INFORMATION FOR CLINICIANS AND EDUCATORS DATABASE

1978-
Bibliographic index to the resource collection of the Project CORK Institute of Dartmouth Medical School, originally founded to develop an alcohol curriculum for use in medical schools/

Journals, books, proceedings, reports
Project CORK Institute

B
L 
AMERICAN BANKER 1981-
Complete text of articles in the daily financial services newspaper, AMERICAN BANKER/

Newspaper

Literature on all aspects of ceramics/

ABSTRACTS

1980-
American Banker, Incorporated

DS, L

AMERICAN BANKER

American Ceramic Society

L, S

Journals, proceedings, patents, reports, books

CERAMIC ABSTRACTS

Information on public, academic, special, and government libraries/

DIRECTORY

Current
R. R. Bowker Company

L
Directory information

\section{AMERICAN LIBRARY DIRECTORY}

\section{AMERICAN MEN AND WOMEN OF SCIENCE 1979-}

A listing of names, addresses, and biographical information on U.S. and Canadian scientists/

Biographical data
R. R. Bowker Company
B, L

\section{ANALYTICAL ABSTRACTS 1982-}

Comprehensive literature on analytical chemistry/

Journals, books, proceedings, reports, standards

\section{AMERICAN MEN AND WOMEN OF SCIENCE, PHYSICAL, AND BIO- LOGICAL SCIENCES}

\section{Royal Society of Chemistry \\ DS, L, S} (U.K.)
AP NEWS

1983-
Full text of the national, international and business news from the Associated Press/
The Associated Press

L

News

Literature relating to petroleum refining and the petrochemical industry/
APILIT

1964-

Journals, proceedings, reports 
APIPAT

1964
Patents relating to petroleum refining and the petrochemical industry issued by the U.S. and eight other countries/
American Petroleum Institute S, STN

Patents

International literature in the applied sciences and technology/

Journals
H. W. Wilson Company

W

APPLIED SCIENCE AND
TECHNOLOGY INDEX
1983-

\section{APPLIED SCIENCE AND TECHNOLOGY INDEX}

\section{APTIC (AIR POLLUTION TECHNICAL INFORMATION CENTER) \\ 1966-1978}

Worldwide literature on air pollution, it's prevention and control/
U.S. Environmental Protection

Agency
L

Journals, monographs, proceedings, patents, government reports

\section{AIR POLLUTION ABSTRACTS}

Information on the growing of marine, brakish, and freshwater organisms/
U.S. National Oceanic and

L
1970-1984

Journals, monographs, proceedings

(NOAA)
AQUALINE

1960
Worldwide coverage of all aspects of water research/

Journals, proceedings, books, reports, legislation, pamphlets, translations, standards
Water Research Centre, S Medmenham Laboratory (U.K.)

WRC INFORMATION
Toxic effects of chemical substances on freshwater and saltwater organisms/

Toxicity data
AQUIRE (AQUATIC INFORMATION RETRIEVAL) 1970-1985
Online catalogue of the British Architectural Library covering all aspects of architecture/

Journals, books, reports, proceedings
U.S. Environmental Protection

I Agency, Office of Toxic Substances

\author{
ARCHITECTURE DATABASE \\ 1978-
}

Royal Institute of British L 
DATA BASE/ DATE OF COVERAGE

\section{ART INDEX}

1984
DESCRIPTION/

PRINCIPAL SOURCES
PRODUCER/

HARD COPY

VENDOR
Literature in the field of art

including archeology, architec-

ture, city planning, design, motion pictures, museum studies

and photography/

Journals

International literature on the history of art/

ART LITERATURE

INTERNATIONAL

1973-
H. W. Wilson Company

W

Journals, books, essays, proceed-

ings, exhibition catalogs, museum

ART INDEX

RILA, The International

L

Repertory of the Literature

of Art

RILA

ARTBIBLIOGRAPHIES
MODERN
1974-

1974
International literature of modern art and design from 1800 to the present/

Journals, dissertations, exhibition catalogues, books
ABC-Clio, Incorporated

L

\section{ARTBIBLIOGRAPHIES MODERN}

ARTHUR D. LITTLE/ONLINE 1977-
Index to the non-exclusive sources of the consulting firm Arthur D. Little, mainly in the areas of management, technology and industry/
Arthur D. Little

Decision Resources
L

Reports

Worldwide information on the major areas of the arts and humanities/

Journals
Institute for Scientific Information

B, L

\section{SEARCH}

1980-

\section{ARTS AND HUMANITIES CITATION INDEX}

L

\section{ASFA (AQUATIC SCIENCES AND FISHERIES ABSTRACTS) 1978-}

International comprehensive literature on the life sciences of seas, inland waters, marine and fresh water/

Journals, books, proceedings, reports
Cambridge Scientific Abstracts

AQUATIC SCIENCES AND FISHERIES ABSTRACTS 
DATA BASE/ DATE OF COVERAGE
DESCRIPTION/

PRINCIPAL SOURCES
PRODUCER/

HARD COPY

VENDOR

ASI (AMERICAN STATISTICS

INDEX)

1973-
Statistical publications of the

Federal government with

emphasis on environmental,

economic, and social aspects/

Journals, reports, statistics
Congressional Information

Service, Incorporated
L

\section{AMERICAN STATISTICS INDEX}

ASSOCIATIONS PUBLICATIONS IN PRINTT

Current
Listing of publications from

associations/
Publications
R. R. Bowker Company

B
ASSOCIATIONS PUBLICA-

TIONS IN PRINT

\section{AVLINE (AUDIOVISUAL CATALOG ON-LINE) \\ Current}

Bibliographic information concerning audiovisual materials in the health sciences/

Films, videotapes, slides, recordings
National Library of Medicine

NLM

\section{NLM's AUDIOVISUAL} CATALOG

Complete text of the modern day revision of the 1769 Bible/

Bible
BIBLE (KING JAMES VERSION) Current
Thomas Nelson Publisher

L
Contains publications in German collected by the German Library in Frankfurt/

Books, theses, journals, reports, maps, proceedings
Deutsche Bibliothek (FRG)

STN
1972
Listing of bibliographies/

Bibliographies

Information on the business applications of biological and biomedical research/

Journals, proceedings
GERMAN NATIONAL BIBLIOGRAPHY
BIBLIOGRAPHIC INDEX

1984
H. W. Wilson Company

W

\section{BIOBUSINESS \\ 1985-}

\section{BIBLIOGRAPHIC INDEX}

BioSciences Information Service

B, DS, L 
BIOCOMMERCE ABSTRACTS 1981-
News items on the business aspects of biotechnology and the commercial applications of the biological sciences/

Newsletters, newspapers, journals
BioCommerce Data Ltd. (U.K.) DS, L

ABSTRACTS IN BIOCOMMERCE

Kennedy Institute of Bioethics, NLM

Information concerning the ethical and public policy aspects in health care or biomedical research/

Journals, newspapers, monographs, court decisions, bills, laws, audiovisuals
Georgetown University

BIBLIOGRAPHY OF BIOETHICS
BIOGRAPHY INDEX

1984-
Guide to biographical information in periodicals and books/

Journals, books
H. W. Wilson Company

W

BIOGRAPHY INDEX

Keys to locations of biographical information found in biographical directories/

Biographical directories
Gale Research Company

L
BIOGRA
Current
International literature in the biological and agricultural sciences;

Journals
BIOGRAPHY AND GENEALOGY MASTER INDEX
W
TURAL INDEX 1983-
H. W. Wilson Company

BIOLOGICAL AND AGRICULTURAL INDEX
BIOMASS

1980-

\section{Literature on energy from} biomass/

Journals, reports, proceedings, books, patents
IEA Biomass Conversion Technical Information Service (Ireland)

BIOMASS ABSTRACTS 
DATA BASE/ DATE OF COVERAGE

\section{BIOSIS PREVIEWS}

1969-
DESCRIPTION/

PRINCIPAL SOURCES
PRODUCER/

HARD COPY

VENDOR

BioSciences Information Service

B, DS, L, STN

Worldwide literature of the life sciences/

Journals, reports, reviews, symposia, books, bibliographies

BIOLOGICAL ABSTRACTS, BIORESEARCH INDEX, BIOLOGICAL ABSTRACTS / REPORTS, REVIEWS, MEETINGS

Technical aspects of biotechnology /

Journals, proceedings, patents
Derwent Publications Ltd.

L, S
Business news items on market opportunities, competitor activities, trends in comsumption and economic activity around the world/
BIOTECHNOLOGY ABSTRACTS

\section{BIS INFOMAT}

1983-

Newspapers, journals, wire services

Business Intelligence Services DS, L
Information on current medical affairs as reported in the media/

Broadcast programs, newspapers
British Medical Association

DS

BMA

Complete text of the BOND BUYER, a newspaper concerning the U.S. municipal bond industry $/$

Newspaper

Citations to reviews of current adult and juvenile fiction and nonfiction/

Books
Bond Buyer, Incorporated

B, L

\section{1-}

BOOK REVIEW DIGEST

1983-
References to reviews of books and periodicals/

Books, periodicals w

H. W. Wilson Company

(1)

\section{BOOK REVIEW INDEX} 1969-
BOOK REVIEW DIGEST

Gale Research Company

BOOK REVIEW INDEX 
DATA BASE/ DATE OF COVERAGE

BOOKS IN PRINT

Current 2 years
DESCRIPTION/

PRINCIPAL SOURCES

\section{PRODUCER/}

HARD COPY
VENDOR
Bibliographic information on print, out of print, and forthcoming book titles/

Books
R. R. Bowker Company
B, L

BOOKS IN PRINT, FORTHCOMING BOOKS IN PRINT, SCIENTIFIC AND TECHNICAL BOOKS IN PRINT, MEDICAL BOOKS IN PRINT

BRITISH BOOKS IN PRINT

Current
Comprehensive index of books published in the United Kingdom/

J. Whitaker \& Sons, Ltd.

L

Books

BRITISH BOOKS IN PRINT

Chad wyck-Healey Incorporated

L
BRITISH OFFICIAL PUBLICATIONS (NON-HMSO) 1980-
Catalog and index of British official publications issued directly by government departments and other government agencies/

Publications catalogs
CATALOGUE OF BRITISH

OFFICIAL PUBLICATIONS NOT PUBLISHED BY HMSO

\section{BUSINESS}

1983-

\section{European database on world-} wide trade opportunities, business contacts for manufacturing, marketing, sales, services, etc.l

Exhibition catalogs and directories, journals, company profiles, corporate data

Online GmbH (West Germany) DS

Articles on companies, products, Predicasts, Incorporated

L

BUSINESS AND INDUSTRY

NEWS

Current industries and marketing/

Newspapers, journals, reports, news releases
BUSINESS DATELINE 1985-
Full text of major news and feature stories from U.S. and Canadian regional business publications/
Data Courier, Incorporated

B, $\mathbf{L}$

Business publications 


\section{DATA BASE/ DATE} OF COVERAGE

\section{BUSINESS OPPORTUNITIES} Current
DESCRIPTION/

PRINCIPAL SOURCES
PRODUCER/

HARD COPY

VENDOR

Details of products or services on a worldwide basis for which supplies are required/
Company Line UK, Ltd.

DS

\begin{tabular}{llll}
$\begin{array}{l}\text { BUSINESS PERIODICALS INDEX } \\
\text { 1982- }\end{array}$ & $\begin{array}{l}\text { International English-language } \\
\text { business literature/ }\end{array}$ & H. W. Wilson Company & W \\
& Journals & $\begin{array}{l}\text { BUSINESS PERIODICALS } \\
\text { INDEX }\end{array}$ & \\
\hline $\begin{array}{l}\text { BUSINESS SOFTWARE } \\
\begin{array}{l}\text { DATABASE } \\
\text { Current }\end{array}\end{array}$ & $\begin{array}{l}\text { Descriptions of business software } \\
\text { packages for micro and mini- } \\
\text { computers/ }\end{array}$ & Data Courier, Incorporated & B, DS, L \\
& Software & & -
\end{tabular}

BUSINESSWIRE

1986-
Full text of news releases issued by corporations and other organizations/

News releases
Business Wire

L

Verlag Hoppenstedt and

DS products manufactured and offered for sale by about 2900

Company (West Germany) companies in Germany, Switzerland, and Austria

$\begin{array}{ll}\text { BUYERS' GUIDE-MEASURE- } & \text { List of measurement and control } \\ \text { MENT AND CONTROL } & \text { products manufactured and } \\ \text { Current } & \text { offered for sale by about 2900 } \\ & \text { companies in Germany, Switzer- } \\ & \text { land, and Austria }\end{array}$

BUYERS' GUIDE-MEASUREMENT AND CONTROL

\begin{tabular}{l} 
\\
\hline CAB ABSTRACTS (COMMON- \\
WEALTH AGRICULTURAL \\
BUREAUX) \\
1973-
\end{tabular}

CAB ABSTRACTS (COMMON-

Comprehensive literature in agriculture, biology, leisure, recreation, and tourism/

Journals, monographs, reports, patents, proceedings, bibliographies
$\mathrm{CAB}$ International
B, L

COMMONWEALTH AGRICULTURAL BUREAUX, JOINT PUBLICATIONS, LEISURE, RECREATION, AND TOURISM ABSTRACTS 
CANADIAN BUSINESS AND CURRENT AFFAIRS 1980-
Canadian company, product, and industry information/

Newspapers, periodicals
Micromedia Ltd. (Ontario)

L
CANADIAN BUSINESS INDEX, CANADIAN NEWS INDEX
CANCERLIT (CANCER LITERATURE) 1963-
National Cancer Institute

B, DS, L, NLM
Articles related to all aspects of cancer/

Journals, reviews, proceedings, government reports
CANCER THERAPY

ABSTRACTS, CARCINO-

GENEISIS ABSTRACTS

Chemical Abstracts Service

STN

Current chemical literature

6-8 weeks before it appears online in CHEMICAL

ABSTRACTS/

Journals, proceedings, reports, books, theses
Listing of college graduates and experienced applicants looking for job placement/

Resume information
Career Placement Registry

L

\section{REGISTRY}

Current
Literature on organic chemical reactions/
Chemical Abstracts Service

STN
1985-

Journals
CASSI (CHEMICAL ABSTRACTS SERVICE SOURCE INDEX) Current
Listing of serial and non-serial publications from resource libraries in 28 countries/

Serials, non-serials
Chemical Abstracts Service

S
CHEMICAL ABSTRACTS SERVICE SOURCE INDEX
CATALYST RESOURCE ON THE WORKFORCE AND WOMEN 1963-
Citations to current information on women in the workforce/
Catalyst Information Center

B
Journals, books, reports, bibliographies 
DATA BASE/ DATE OF COVERAGE
DESCRIPTION/ PRINCIPAL SOURCES
PRODUCER/

HARD COPY

VENDOR
CATLINE (CATALOG ON-LINE) Listing of all monographs and 1965-
National Library of Medicine

NLM

the National Library of Medicine/

Monographs, serials

\section{CURRENT CATALOG}

National Cancer Institute, NIH I, NLM

Contains assay results and test conditions for 1088 chemicals in the area of carcinogenicity, mutagenicity, tumor promotion and cocarcinogenicity/

Data GENESIS RESEARCH INFORMATION SYSTEM)

1986

Statistical data, press releases and product information from the Bureau of the Census/

Censuses, surveys

\section{CENDATA \\ Current}

Detailed information and evaluations on a group of chemicals of importance to the Great Lakes Basin/

Chemical data
Michigan Dept. of Natural Resources
U.S. Bureau of the Census

L
CESARS (CHEMICAL EVALUASYSTEM)

Current
Computerized bulletin board which includes information on the computer programs, conferences, publications, database and resource directory of the Center for Fire Research at NIST/
Center for Fire Research, National Institute of Standards and Technology (NIST)

\section{CHEM-INTELL}

Current
Worldwide chemical plant information, trade statistics and production statistics for more than 100 organic and inorganic chemicals/

Company information
Chem-Intell, Chemical Intelligence DS, L Services (UK)
I

C
CFRBBS
Current 
CHEMDEX

1972-
Compound-oriented file containing registry numbers, molecular formulas, and nomenclatures/
Chemical Abstracts Service

\section{$S$}

CHEMICAL ABSTRACTS SUBSTANCE INDEX, CHEMICAL ABSTRACTS REGISTRY HANDBOOK, CHEMICAL ABSTRACTS INDEX GUIDE, CHEMICAL ABSTRACTS FORMULA INDEX
CHEMICAL ABSTRACTS

$1967-$
Worldwide literature in chemistry and chemical engineering/

Journals, books, reviews, patents, reports, proceedings, dissertations
Chemical Abstracts Service

B, DS, L, S, STN
CHEMICAL ABSTRACTS

U.S. Envirenmental Protection

Lists of chemicals that EPA is studying or has studied in the course of its regulatory or scientific research activities/

\section{I}

REPORT (CASR)

1984

Chemicals

$\begin{array}{llll}\text { CHEMICAL BUSINESS NEWS } & \begin{array}{l}\text { Covers trends and current affairs } \\ \text { in the chemical industry and } \\ \text { end-markets/ }\end{array} & \begin{array}{l}\text { Royal Society of Chemistry } \\ \text { (U.K.) }\end{array} & \text { DS, L } \\ \begin{array}{ll}\text { October 1984- } & \text { Journals }\end{array} & -\end{array}$

CHEMICAL ENGINEERING
ABSTRACTS
1970-

\section{ABSTRACTS}

Theoretical and practical material in all aspects of chemical engineering/
Royal Society of Chemistry (U.K.)
DS, L, S

Journals

Chemicals identified in tissues and body fluids for human, feral and food animals/

Journals, proceedings, letters, reports Laboratory

CHEMICALS IDENTIFIED IN HUMAN BIOLOGICAL MEDIA, A DATA BASE; CHEMICALS IDENTIFIED IN FERAL AND FOOD ANIMALS, A DATA BASE
Chemical Effects Information Center, Oak Ridge National

L 1974 


CHEMICAL HAZARDS IN
INDUSTRY
1984-

CHEMICAL HAZARDS IN

1984
Literature on hazards caused by chemicals likely to be encountered in the chemical and allied industries/
Royal Society of Chemistry

DS, STN

Journals, books, proceedings, audiovisual material

\section{CHEMICAL REGULATIONS AND GUIDELINES SYSTEM May 1981-}

Guide to U.S. government regulatory material relating to the control of chemical substances/

Regulations
(U.K.)
CRC Systems, Incorporated L

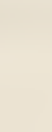


DATA BASE/ DATE

OF COVERAGE
DESCRIPTION/

PRINCIPAL SOURCES
PRODUCER/

HARD COPY
VENDOR
CHRIS (CHEMICAL HAZARD RESPONSE INFORMATION SYSTEM)

Current
Information on 1016 hazardous chemicals such as properties, health hazards, and first aid/
U.S. Coast Guard

I

Chemical data

Business-oriented literature in the chemical industry/

Journals

Index and abstracts of U.S.

congressional publications/

INFORMATION SERVICE) 1970-
NOTES)

1974
Chemical Abstracts Service

DS, L, S

\section{CHEMICAL INDUSTRY NOTES}

Congressional Information

L
Service

Hearings, reports, documents, CIS INDEX public laws

\begin{tabular}{lll} 
CJACS & $\begin{array}{l}\text { Full text of American Chemical } \\
\text { Society journals/ }\end{array}$ & American Chemical Society \\
& Journals & Various ACS Journals \\
\hline CJAOAC & $\begin{array}{l}\text { Full text of papers included in } \\
\text { JOURNAL OF THE ASSOCIA- }\end{array}$ & $\begin{array}{l}\text { Association of Official Analytical } \\
\text { Chemists }\end{array}$ \\
& $\begin{array}{l}\text { TION OF OFFICIAL ANALY- } \\
\text { TICAL CHEMISTS/ }\end{array}$ & \\
& Journal & JOURNAL OF THE ASSOCIA- \\
& TION OF OFFICIAL ANALY- \\
& & TICAL CHEMISTS
\end{tabular}

CIRSC

1987-
Full text of the chemical journals of the Royal Society of Chemistry/

Journals

Full text information from polymer journals!
Royal Society of Chemistry (U.K.)
STN

STN TION OF OFFICIAL ANALY-

CJWILEY

1987-
John Wiley and Sons, Incorporated STN

Various Wiley journals 
DATA BASE/ DATE OF COVERAGE

CLAIMS/CITATION 1947-
DESCRIPTION/ PRINCIPAL SOURCES
PRODUCER/

HARD COPY
VENDOR

IFI/Plenum Data Company

L, S, STN

A listing of U.S. patents and cited references/

Patents

A series of six files listing U.S.

IFI/Plenum Data Company

L, S, STN patents issued by the U.S. Patent and Trademark Office/

Patents
U.S. PATENT OFFICIAL GAZETTE

\section{CLAIMS/REFERENCE Current}

Dictionary index to the U.S.

Patent Office's classification codes/
IFI/Plenum Data Company

L, S, STN

Patents

Human clinical articles selected from the general medical literature/

Journals
Medical Information Systems

L 19811984

Compilation of case notes submitted by clinicians concerning notable cases/

Case notes
Summaries of clinical investigations on new anticancer agents and treatment/

National Cancer Institute, National Institutes of Health (NIH)
On-going research
DS

Elsevier (U.K.)

\section{CNMR (CARBON-13 NUCLEAR MAGNETIC RESONANCE SPECTRAL SEARCH SYSTEM)} Current

CLINPROT (CLINICAL
PROTOCOLS)
Current

\section{COFFEELINE 1973-}

Nonbibliographic data on spectra pertaining to 11,693 compounds/

\section{Data}

\author{
Covers research and factual infor- International Coffee Organization \\ mation on many aspects of coffee/ (U.K.) \\ Journals, reports, books, patents, \\ theses, audiovisual material \\ ICO LIBRARY MONTHLY \\ ENTRIES
}

National Institutes of Health

I, STN

(NIH), Environmental

Protection Agency (EPA),

Netherlands Information Combine

NLM 
DATA BASE/ DATE
OF COVERAGE

COLD REGIONS

1951-

\section{DESCRIPTION， \\ PRINCIPAL SOURCES \\ PRODUCER/ \\ HARD COPY}

VENDOR
Worldwide literature pertaining to snow, ice, permafrost, and frozen ground and their relation to civil engineering, navigation, and transportation/

Reports, journals, books, proceedings, patents
Cold Regions Research and

\section{S}

Engineering Laboratory of the

U.S. Army Corps of Engineers/

Library of Congress

\section{ANTARCTIC BIBLIOGRAPHY, BIBLIOGRAPHY ON COLD REGIONS SCIENCE AND TECHNOLOGY}

\begin{abstract}
COMBINED HEALTH INFORMATION DATABASE 1977-(varies)

Information on arthritis, diabetes, heal th education, digestive diseases and high blood pressure/

Journals, pamphlets, monographs,
audio-visuals, reports, proceedings

Journals, pamphlets, monographs,
audio-visuals, reports, proceedings
\end{abstract}

Combined Health Information

B

Database

COMMERCE BUSINESS DAILY

October 1982-
Announcements of products and services wanted or offered by the U.S. government/

Contract awards or announcements
U.S. Dept. of Commerce

L

\section{COMMERCE BUSINESS DAILY}

Worldwide engineering and
technological literature/ INDEX) 1970-
Journals, transactions, proceedings, government reports
Engineering Information, Incorporated
B, DS, L, S, STN
Access to the complete text of 24 prominent medical textbooks/

\section{ENGINEERING INDEX}

B

\section{COMPREHENSIVE CORE MEDICAL LIBRARY}

Current

\section{Textbooks}

COMPUTER AND MATHEMATICS SEARCH

1980-
Literature in mathematics, computer science, statistics, operations research and related fields/

Journals
Institute for Scientific Information

B

\section{COMPUMATH CITATION INDEX}

THE COMPUTER DATABASE 1983-
Technical and consumer informa- Information Access Company tion on computers, telecommunications and electronics/

Journals, newsletters, proceedings
B, DS, L, M

\section{,}


DATA BASE/ DATE OF COVERAGE

COMPUTERPAT

1942-
DESCRIPTION/

PRINCIPAL SOURCES
PRODUCER/

HARD COPY
VENDOR
U.S. digital data processing patent Pergamon Orbit InfoLine documents/ Incorporated
S

Patents
CONF

1976-
Information on past, current and future conferences on energy, physics, mathematics, computer

sciences and engineering/

Conferences
FIZ Karlsruhe (F.R. Germany)

STN

\section{CONFERENCE PAPERS INDEX}

(CPI)

1973-
Scientific and technical papers presented at conferences/

Proceedings
Cambridge Scientific Abstracts

L

CONFERENCE PAPERS

INDEX

\section{CONSUMER DRUG INFORMA- TION FULLTEXT \\ Current}

Full text drug descriptions written in everyday language for the consumer patient/

Drug information
American Society of Hospital

Pharmacists

B, L

\section{CONSUMER DRUG DIGEST}

\section{CONSUMER REPORTS}

1982-
Complete text of major articles from CONSUMER REPORTS/

Journal
Consumers Union

L

\section{CONSUMER REPORTS}

National Register Publishing

Company

L businesses and corporate linkages to parent organizations/

Directory information
CORPORATE AFFILIATIONS Current
Index to company and industry research reports issued by major U.S. and Canadian securities and institutional investment firms/
J A Micropublishing, Incorporated B

\section{Reports}

CORPORATE AND INDUSTRY

RESEARCH REPORTS INDEX

\section{CORROSION \\ Current}

Corrosive data covering the ef- Marcel Dekker fects of over 600 agents on metals, carbons, glass, plastics and rubber/

Data
CORROSION RESISTANCE

TABLES: METALS, PLASTICS, NONMETALLICS AND RUBBERS 


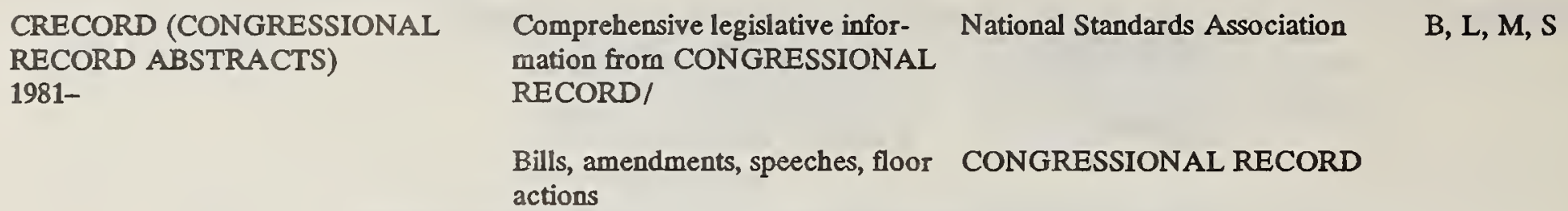

Comprehensive legislative infor- National Standards Association mation from CONGRESSIONAL RECORD/

Bills, amendments, speeches, floor

CONGRESSIONAL RECORD actions

CRIMINAL JUSTICE PERIODICAL INDEX

1975-
Covers areas of criminology, criminal law, security systems, corrections and police/

Journals
University Microfilms International L

CRIMINAL ЛUSTICE PERIOD-

ICAL INDEX

USDA, Current Research

\section{CRIS/USDA}

Current
Listing of current research projects in agriculture and related subjects/
L

Research projects

Catalog file containing informa-

tion about chemical products and their suppliers/

Catalog information

Directory information about companies that supply chemicals and chemical products/

Directory information
Directories Publishing Company, STN Incorporated

\section{CHEM SOURCES-USA}

Directories Publishing Company, STN Incorporated

\section{CHEM SOURCES-USA}

CTCP (CHEMICAL TOXICOLOGY OF COMMERCIAL PRODUCTS) 1984
Listing of manufacturers, trade names, uses, and ingredients of commercially available products/

Data
Dartmouth Medical School; COMMERCIAL PRODUCTS

Cuadra/Elsevier

DS, S

Information about online databases/

ONLINE DATABASES

Current

Databases

DIRECTORY OF ONLINE DATABASES 
CULP (CALIFORNIA UNION

LIST OF PERIODICALS)

Current
A finding list of periodicals and serials held by California libraries/

Periodicals
California Library Authority

B for Systems and Services

CALIFORNIA UNION LIST OF PERIODICALS (Microfiche)
CUMULATIVE BOOK INDEX 1982-
Listing of books published anywhere in the world in the English language/
H. W. Wilson Company

W

Books

CUMULATIVE BOOK INDEX

$S$
CURRENT AWARENESS IN THE Listing of worldwide biological BIOLOGICAL SCIENCES $1983-$ literature/
Pergamon Press

\section{Journals}

Literature on the scientific, technical and technocommercial aspects of biotechnology/

Journals
Royal Society of Chemistry

DS, $L, S$

\section{ABSTRACTS}

1983-

\section{(U.K.)}

.


DATA BASE/ DATE OF COVERAGE
DESCRIPTION! PRINCIPAL SOURCES
PRODUCER/

HARD COPY
VENDOR

D\&B-CANADIAN DUN'S
MARKET IDENTIFIERS
Current

Current
Financial data for 350,000

Canadian companies/
Dun's Marketing Services

L

Business data

\section{D\&B-DUN'S ELECTRONIC YELLOW PAGES \\ Current}

Directory information for nearly 8.5 million businesses and professionals throughout the United States/

\section{Dun's Marketing Services}

L

Data from interviews

D\&B-DUN'S FINANCIAL
RECORDS
Current

D\&B-DUN'S FINANCIAL Current
Financial information on U.S. Dun's Marketing Services private and public business establishments/

Financial data

\section{D\&B-DUN'S MARKET IDENTIFIERS \\ Current}

Directory file containing address, financial and marketing information on U.S. business establishments/

Financial and marketing data
Dun's Marketing Services

L
L

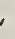

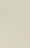



DATA BASE/ DATE
OF COVERAGE
DESCRIPTION/

PRINCIPAL SOURCES
Detailed information on publicly available databases/

Databases
M. E. Williams, Incorporated

L

COMPUTER-READABLE

DATABASES: A DIRECTORY

AND DATA SOURCEBOOK

\begin{abstract}
DATAPRO PERSONAL COMPUTER SOFTWARE Current
\end{abstract}

Full text dataoase which provides descriptions of software programs for personal computers/

Software
Datapro

DS

Software
DE HAEN DRUG DATA
1980-
Reports on drugs from 1200 major Paul de Haen International, international biomedical journals/ Incorporated

Journals

\section{DECHEMA}

1975-
References to the German and international literature in the fields of chemical technology, biotechnology, chemical equipment, pollution control and safety technology/

Journals, reports, proceedings, books
DECHEMA (Deutsche
L
DECHEMA (Deutsche

STN
DEQUIP (DECHEMA EQU
SUPPLIER DATA BANK) Current
Information on manu apparatus and technical equipment in the fields of chemical engineering and biotechnology/

Data

Dermal absorption of chemical substances/
Gesellschaft fur Chemisches

Apparatewesen)

\section{ACHEMA YEARBOOK}

U.S. Environmental Protection

\section{I} Agency, Office of Pesticides and Toxic Substances

Chemical data

\begin{abstract}
DETEQ (DECHEMA ENVIRONMENTAL TECHNOLOGY EQUIPMENT DATA BANK)

Current
\end{abstract}

Information on manufacturers of apparatus and technical equipment in the fields of environmental engineering/

\section{Data}

DECHEMA (Deutsche Geseilschaft für Chemisches Apparatewesen)

ACHEMA HANDBOOK POLLUTION CONTROL 
DEUTSCHE PATENT DATENBANK (GERMAN PATENT DATABASE)

1981-
Bibliographic data in German on patent documents and utility models published by the German patent office/
Deutsches Patentamt

STN

Patents
DHSS-DATA

1983-
Online database of the Department of Health and Social Security Library in London/

Journals, books, reports, pamphlets
Department of Health and Social

DS
Gateway service which provides stock and option quotes from the New York and American Stock Exchange, NASDAQ and the four major option exchanges/

Stock exchange quotes
Trade Plus

L

\section{TRADING}

Current
Full text of published and unpublished regulatory information

FOI Services, Incorporated

B, DS, L

Current concerning the health care industry/

Regulations, newsletters

DIPPR (DESIGN INSTITUTE FOR PHYSICAL PROPERTY DATA) 1982-
Textual information and numeric physical property data for commercially important chemical substances/
American Institute of Chemical

STN

\section{Chemical data}

DIRECTORY OF AMERICAN RESEARCH AND TECHNOLOGY Current
Listing of the research and development capabilities of industrial organizations in the U.S.I

\section{Engineers}

R. R. Bowker Company

S

Questionnaires 
DATA BASE/ DATE OF COVERAGE
DESCRIPTION/

PRINCIPAL SOURCES
PRODUCER/

HARD COPY

VENDOR

\section{DIRECTORY OF GRADUATE} RESEARCH

Current
Full text information on colleges and universities offering degrees in chemistry and biochemistry/

Directory information
American Chemical Society

B

\section{DIRECTORY OF GRADUATE} RESEARCH

\section{DIRLINE (DIRECTORY OF INFORMATION RESOURCES ONLINE) \\ Current}

Directory of organizations providing information in specific subject areas/

Directory information
DISCLOSURE FINANCIALS Current
Information extracted from
Disclosure Information Group
B, L reports filed with the SEC by
10,000 publicly-held companies/
Reports

\begin{abstract}
DISCLOSURE MANAGEMENT Current
\end{abstract}

Detailed management information Disclosure Information Group on 10,000 publicly-held companies/

B, L

Reports
Detailed and summary ownership information for about 5000 public

Disclosure, Incorporated

B, L

\section{OWNERSHIP}

Current companies/

Data

\section{DISSERTATION ABSTRACTS ONLINE \\ 1861-}

\section{Listing of doctoral and master} dissertations granted by U.S. universities and other countries/

Dissertations
University Microfilms International B, L

DISSERTATION ABSTRACTS

INTERNATIONAL, AMERICAN

DOCTORAL DISSERTATIONS
DMS CONTRACT AWARDS FY1981-

\begin{abstract}
Comprehensive listing of nonclassified U.S. government prime contracts of $\$ 25,000$ or more/

Contracts
\end{abstract}

DMS Incorporated

L

\section{DMS CONTRACTORS 1969}

Companies involved in U.S. and international defense/aerospace programs/

Unclassified information sources
DMS Incorporated 
DMS DEFENSE NEWSLETTERS 1982-
Complete text of defense newsletters/

Newsletters
DMS Incorporated

L

Various newsletters
DONNELLEY DEMOGRAPHICS

1980 census data
Demographic data from the 1980 census/

Demographic data
Donnelley Marketing Information L Services

Services

Multidisciplinary coverage of classified and unclassified technical reports generated by U.S. government sponsored research; also includes publications of NIST's National Standard Reference Data System (NSRDS)/

Reports
Defense Technical Information Center (DTIC)
D ON-LINE SYSTEM)

1953-
TECHNICAL ABSTRACT BULLETIN
DRUG (DRUG INFO ALCOHOL USE-ABUSE)

1968-
Diversified coverage of the drug abuse literature/
College of Pharmacy, University of Minnesota and Hazelden

Foundation
B

Journals, reviews, unpublished reports

\section{DRUG INFORMATION \\ FULLTEXT \\ Current}

Information on drug uses, precautions, interactions, dosages, etc./

\section{HANDBOOK ON INJECTIBLE} DRUGS; AMERICAN HOSPITAL FORMULARY SERVICE DRUG INFORMATION
American Society of Hospital Pharmacists

B, I, L

HANDBOOK ON INJECTIBLE

DRUGS; AMERICAN HOSPI-

TAL FORMULARY SERVICE DRUG INFORMATION

Business International (Austria)

EAST EUROPEAN CHEMICAL

Business information from the chemical industry sector/

1984-

Journals

Energy related literature/

AND INDEX)

1866-
Texas A \& M University Library/ S

Gulf Publishing Company

Reports, vertical file information
ENERGY BIBLIOGRAPHY AND INDEX 


\section{ECER (EXCEPTIONAL CHILD EDUCATION RESOURCES) \\ 1966-}

Published and unpublished literature on education of handicapped and gifted children/

Journals, monographs, reports
Council for Exceptional Children B, L

EXCEPTIONAL CHILD EDUCATION ABSTRACTS

\section{ECON (ECONOMICS, DEVELOP- Literature of the applied social MENT AND EDUCATION) \\ sciences including economics, \\ 1980 \\ geography, sociology, education, and psychology/ \\ Journals, reports, monographs, thesis}

$\mathrm{CAB}$ International

B

ECON BASE: TIME SERIES AND
FORECASTING
1948-

1948-

Compilation of critical economic data used for researching, monitoring and reporting economic, financial and industry specific trends/

Statistical data

Worldwide literature on all aspects of economics/

Journals

\section{Chase Econometrics}

L

\section{ECONOMIC LITERATURE INDEX \\ 1969}

American Economics Association

L
INDEX OF ECONOMICS ARTICLES, JOURNAL OF ECONOMICS LITERATURE

\section{EDB (DOE ENERGY DATA \\ BASE) \\ 1974}

International literature on energy and related fields/

Scientific and technical reports, books, proceedings, patents, journals
Department of Energy, Technical Information Center

\section{L, STN}

\section{ENERGY RESEARCH}

ABSTRACTS, ENERGY

ABSTRACTS FOR POLICY ANALYSIS

\section{EDUCATION INDEX \\ 1983-}

Literature on all areas of education/

Journals

Descriptions of tests, evaluation tools and assessment/screening SERVICE FILE Current devices for measuring skills, aptitudes, interests, etc./
H. W. Wilson Company

W

\section{EDUCATION INDEX}

Educational Testing Service

B

Tests 
DATA BASE/ DATE OF COVERAGE

EI ENGINEERING MEETINGS July 1982
DESCRUPTION/

PRINCIPAL SOURCES
PRODUCER/

HARD COPY
VENDOR

DS, S, STN

Published proceedings of engin-

eering and technical conferences/

Engineering Information,

Incorporated

EI ENGINEERING CONFERENCE INDEX
Proceedings

\section{ELECTRO/ELECTRONICS BUYERS' GUIDE \\ Current}

Listing of electrical and electronic products manufactured and offered for sale by about 1,950 companies in Germany/
Verlag W. Sachon, GmbH and

DS
Latest data on properties of materials important in the fields of microelectronics and solid state research/
Inspec, Institution of Electrical Engineers INFORMATION SERVICE 1982-

Journals

Literature in electronic publishing PIRA (U.K.) and information technology/
$\mathbf{S}$

\section{ELECTRONIC PUBLISHING ABSTRACTS 1975-}

Journals, books, proceedings, standards, reports
ELECTRONIC SELECTIVE ARCHIVES 1983-
Business and economic news of ELSA (Switzerland)

DS
B 


\section{DATA BASE/ DATE OF COVERAGE}

DESCRIPTION/ PRINCIPAL SOURCES
PRODUCER/

HARD COPY

VENDOR
ENERGIE

1976-
Literature on energy research and technology published in

German speaking countries/
FIZ Karlsruhe (F. R. Germany)

STN

Journals, reports, books, patents, proceedings

\begin{tabular}{|c|c|c|}
\hline \multirow[t]{2}{*}{$\begin{array}{l}\text { ENERGYLINE } \\
\text { 1971- }\end{array}$} & $\begin{array}{l}\text { Comprehensive coverage of as- } \\
\text { pects of energy and environment/ }\end{array}$ & Environment Information Center \\
\hline & $\begin{array}{l}\text { Journals, reports, monographs, } \\
\text { hearings }\end{array}$ & $\begin{array}{l}\text { ENERGY INFORMATION } \\
\text { ABSTRACTS, ENVIRONMENT } \\
\text { ABSTRACTS }\end{array}$ \\
\hline
\end{tabular}

L, S

Comprehensive coverage of as-
pects of energy and environment/ ABSTRACTS,
ABSTRACTS

\section{ENGINEERED MATERIALS} ABSTRACTS (EMA)

1986-
World's literature on polymers, ceramics, and composites/

Journals, proceedings, reports, books, theses, patents
Materials Information

L, S

\section{ENGINEERED MATERIALS} ABSTRACTS

\section{ENGINEERING AND INDUS- TRIAL SOFTWARE DIRECTORY Current}

Software packages for engineering, manufacturing and industrial applications/
Engineering Information Incorporated
DS

Software

\section{ENVIROFATE}

1970
Environmental fate or behavior of chemical substances released into the environment/

Environmental data
U.S. Environmental Protection

I Agency, Office of Pesticides and Toxic Substances

\section{ENVIROLINE}

1971-
Worldwide coverage of literature in environmental studies/

Journals, new releases, reports, patents, films
Environment Information

L, S 
EPD (ELECTRIC POWER DATA

BASE)

1972-
Summaries of ongoing and completed research projects in the electric utility industry/
Electric Power Research Institute
L

Research projects

\begin{abstract}
EPIA (ELECTRIC POWER INDUSTRY ABSTRACTS) 1975-
\end{abstract}

Literature on electric power plants and related facilities/

Reports, journals, proceedings, testimony
Edison Electric Institute

S

ERIC (EDUCATIONAL
RESOURCES INFORMATION
CENTER)
1966-

ERIC (EDUCATIONAL CENTER)

1966-
Literature in education, social sciences, and educational-related areas/

Journals, research reports, ephemera
Educational Resources

Information Center, National

Institute of Education

\section{INFORUM}

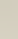


DATA BASE/ DATE OF COVERAGE
DESCRIPTION/ PRINCIPAL SOURCES
PRODUCER/

HARD COPY
VENDOR
FAMILY RESOURCES

1970
Literature concerning marriage and the family/

Journals, books, reports, nonprint materials
National Council on Family

B, L
Relations

Literature in German on projects FIZ Karlsruhe (F.R. Germany) STN

NTIS (National Technical

Information Service)
B
DIRECTORY OF FEDERAL AND STATE ASSISTANCE
Center for the Utilization of Federal Technology, National Technical Information Service (NTIS)

Directory information

\section{FEDERAL RESEARCH IN PROGRESS \\ Current}

Information about ongoing federally-funded research projects in the fields of physical sciences, engineering and life sciences/
National Technical Information

L
B sponsored by the Bundesministerium

für Forschung und Technologie/

Books, reports, projects
Federal and state assistance for businesses/

Directory information

\begin{tabular}{ll}
$\begin{array}{l}\text { FBR (RESEARCH REPORTS } \\
\text { FEDERAL REPUBLIC OF } \\
\text { GERMANY) } \\
\text { 1985- }\end{array}$ & $\begin{array}{l}\text { Literature in German on projects } \\
\text { sponsored by the Bundesministeriu } \\
\text { für Forschung und Technologie/ }\end{array}$ \\
& Books, reports, projects \\
\hline $\begin{array}{l}\text { FEDERAL AND STATE } \\
\text { BUSINESS ASSISTANCE } \\
\text { Current }\end{array}$ & $\begin{array}{l}\text { Federal and state assistance for } \\
\text { businesses/ }\end{array}$ \\
& Directory information \\
\hline $\begin{array}{l}\text { FEDERAL APPLIED TECH- } \\
\text { NOLOGY DATABASE }\end{array}$ & $\begin{array}{l}\text { Federally developed technologies } \\
\text { that have applications to the } \\
\text { private sector/ }\end{array}$
\end{tabular}

\section{FEDERAL APPLIED TECH- NOLOGY DATABASE}

Current
Federally developed technologies that have applications to the private sector/

Research summaries

\section{FEDREG}

1977-
Federal government activities reported in FEDERAL REGISTER/

Regulations, notices, rules
National Standards Association

B, I, L, M, S

\section{FEDERAL REGISTER ABSTRACTS}

Information Center for Regional

STN

References to publications of the Fraunhofer Society Institute in the areas of microelectronics, sensor technology, automated production, and building materials/

Books, journals, conferences, reports, bibliographies
Planning and Building Construction of the Fraunhofer Society 
FINANCIAL TIMES COMPANY ABSTRACTS

March 1982-
Company information abstracted

from the London and International

D-S Production Ltd. (U.K.)

DS, L editions of the FINANCIAL

TIMES newspapers/

Newspaper

Complete text of all articles published in the London and International edition of the FINANCIAL TIMES

newspaper/

Newspaper

\section{FINANCIAL TIMES}

Financial T'imes Business

DS, L
1986-
Describes industry and market research reports and studies commercially available from U.S. and non-U.S. publishers/

Surveys
FINDEX REPORTS AND

STUDIES

1977-
National Standards Association L

\section{FINANCIAL TIMES}


FOOD SCIENCE AND TECHNOLOGY ABSTRACTS (FSTA) 1969
Literature of research and development in food science and technology/

Journals, patents, monographs
PRODUCER/

HARD COPY

VENDOR
International Food Information DS, L, S Service (U.K.)

FOOD SCIENCE AND TECHNOLOGY ABSTRACTS

K \& M Publications, Incorporated I

Information relating to food industry developments/

Journals

FOODS ADLIBRA

\section{4}

Worldwide literature on markets, investment climates, and economic situations in all industries/

Journals, directories, reports
Economic Information Service of the Dutch Ministry for Economic Affairs

ECONOMIC TITLES AND ABSTRACTS

\section{DS, L} ECONOMIC ABSTRACTS 1974
Listing of firms that import goods from the U.S.I
U.S. Department of Commerce

L

\section{(FTI)}

Latest 4 years

Reports

$\begin{array}{ll}\text { FORENSIC SCIENCE DATABASE } & \begin{array}{l}\text { Literature on the examination of } \\ \text { evidential materials, analytical } \\ \text { methods, and the presentation } \\ \text { and interpretation of findings/ }\end{array} \\ & \text { Journals }\end{array}$

FORENSIC SCIENCE DATABASE Literature on the examination of evidential materials, analytical methods, and the presentation

Journals
Worldwide coverage of the wood product industry/

Journals, reports, proceedings
Central Research Establishment,

DS Service (U.K.)

\section{FOREST}

1947-
Forest Product Research

Society
$S$

Informationszentrum

Sozial wissenschaften (FRG)
FORIS
Current, planned and research projects in the social sciences carried out in the Federal Republic of Germany, Austria and Switzerland/

Research projects

TN


FORKAT

Current
Descriptions of research and technology development projects supported by the Federal Ministry for Research and Technology/

Projects
Der Bundesminister für

STN
Forschung und Technologie

BMFT SUPPORT CATALOG

FOUNDATION DIRECTORY

Current
Descriptions of nongovernmental, The Foundation Center nonprofit organizations/

Reports

Information on grants by nongovernmental, nonprofit foundations/

1973
Reports, news releases

Complete coverage of Frost \& Sullivan market research reports/

\section{FOUNDATION DIRECTORY}

L

The Foundation Center

L
FROST \& SULLIVAN MARKET RESEARCH REPORTS 1978-
Reports
FROST \& SUILIVAN POLITICAL RISK COUNTRY REPORTS Current
Assessment of the political and economic conditions in the 85 countries most important to international business/

Reports
Frost \& Sullivan, Incorporated

DS
Frost \& Sullivan, Incorporated B, DS

FOUNDATION NEWS 
DATA BASE/ DATE OF COVERAGE

GENERAL SCIENCE INDEX 1984
DESCRIPTION/

PRINCIPAL SOURCES
PRODUCER/

HARD COPY

VENDOR
Literature in the physical, life, and health sciences/

Journals

Mutagenicity information on more than 2600 chemicals as tested against 38 biological systems/

Data
H. W. Wilson Company

W

GENERAL SCIENCE INDEX

U.S. Environmental Protection I Agency, Office of Pesticides and Toxic Substances

\section{DATABASE)}

Current
International coverage of the

literature of the geosciences/

Journals, books, proceedings, reports

\section{Geosystems (U.K.)}

L
Worldwide literature on geography, geology, ecology and related disciplines/

Journals, books, proceedings, reports
Geo Abstracts Ltd. (U.K.)

L

1980 engineering geology/

Journals, proceedings, reports

Worldwide coverage of the literature of the geosciences/

Journals, proceedings, symposia, theses
Literature pertaining to rock mechanics, soil mechanics and

Pergamon Press Ltd. (U.K.)

S

1977

\section{GEOREF (GEOLOGICAL REFERENCE FILE) \\ 1785-}

Various Abstract Sources

\section{GEOMECHANICS ABSTRACTS}

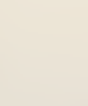

$\begin{array}{ll}\text { GEOARCHIVE } & \text { International coverage of the } \\ \text { 1974- } & \text { literature of the geosciences/ } \\ & \text { Journals, books, proceedings, } \\ \text { reports }\end{array}$


THE GERMAN INDUSTRYMADE IN GERMANY

Current
Detailed information on 18,000 major export-oriented German companies and their products/
Verlag W. Sachon

$\mathrm{GmbH}$ and Company

(West Germany)
DS

\section{GFI (GMELIN FORMULA INDEX) Formula index and complete 1924-1979 (INDEX) 1924-1986 (CATALOG) \\ catalog supplements to GMELIN HANDBOOK OF INORGANIC CHEMISTRY/}

Chemical data
Gmelin Institut fur Anorganische STN

Chemie der Max-Planck-

Gesellschaft zur Foerderung

der Wissenschaften

FORMULA INDEX FOR THE

GMELIN HANDBOOK OF

INORGANIC CHEMISTRY,

GMELIN COMPLETE CATALOG
$\mathbf{G}$

Cooperative activity between

exchange technical data/

GIDEP Operations Center INDUSTRY DATA EXCHANGE PROGRAM)

1970-

Reports, engineering, metrology,

failure and safety data

GPO MONTHLY CATALOG
1976-
Index of public documents of the Federal governement/

Reports, hearings, laws, bills

Government Printing Office (GPO)

B, L, W

MONTHLY CATALOG OF U.S. GOVERNMENT PUBLICATIONS

Peterson's Guides

L

GRADLINE

Current
Information on graduate and professional programs offered by accredited colleges and universities in the U.S. and Canada/

Survey data
PETERSON'S ANNUAL GUIDES/GRADUATE STUDY

\section{GRANTS}

Current
Grant programs offered by government and nongovernment organizations/

Directories, bulletins
Oryx Press

L
GRANT INFORMATION SYSTEM, FACULTY ALERT BULLETIN 
GUIDE TO MICROFORMS IN PRINT

Current
International guide to microform Meckler Publishing

B publications/

Microforms
GUIDE TO MICROFORMS

IN PRINT

\section{HARFAX INDUSTRY DATA SOURCES \\ 1979-}

Identifies and describes sources of marketing and financial data on 65 key industries/

Reports, directories, handbooks, theses, yearbooks, journals

\section{Information Access Company}

DS
Full text coverage of HARVARD John Wiley and Sons BUSINESS REVIEW'S complete range of management subjects/

\section{HARVARD BUSINESS REVIEW}

HARVARD BUSINESS REVIEW

HARVARD BUSINESS REVIEW/
ONLINE (HBRO)
1971-

ONLINE (HBRO)

1971
Regulatory, handling, identification, and emergency care information for over 3000 hazardous substances/

Regulations

\section{HAZARDLINE}

Current
Nonbibliographic data on toxicology of potentially hazardous chemicals/

Monographs, reports, journals

B, DS, L

\section{HAZARDOUS SUBSTANCES DATA BASE}

Current
International literature of the nonclinical aspects of health care delivery/

Journals, monographs, symposia
Occupational Health Services, Incorporated
Occupational Safety and Health Administration
B

NLM

National Library of Medicine

B, L, NLM
HEALTH (HEALTH PLANNING AND ADMINISTRATION) 1975-
Listing of audiovisual packages in the health field/
Northeastern Ohio Universities

College of Medicine

\section{B}

ONLINE CATALOG (HAVC) 1960-

\section{HOSPITAL LITERATURE} INDEX

\section{Audiovisuals}


HEALTH INDUSTRY RESEARCH REPORTS

1982-
Reports on health related companies and the health industry/
JA Micropublishing, Incorporated B

Reports

\section{HEILBRON}

Latest edition
Physical/chemical data and bibliographic references to over 175,000 chemical substances/

Property data, journals
Chapman and Hall, Ltd.

L
DICTIONARY OF ORGANIC COMPOUNDS, DICTIONARY OF ORGANOMETALLIC COMPOUNDS
HISTLINE (HISTORY OF MEDICINE ONLINE) 1970-
International literature on the history of medicine/

Journals, monographs, symposia

Worldwide coverage of the literature of history and related social sciences and humanities/

Journals
National Library of Medicine

NLM
HISTORICAL ABSTRACTS 1973-
ABC-Clio, Incorporated

L

\section{BIBLIOGRAPHY OF THE} HISTORY OF MEDICINE
B 
HOPPENSTEDT NETHERLANDS Current
Profiles of 20,000 companies in the Netherlands/

Company information
$A B C$ Voor Handel en Industrie

DS

(Netherlands)

NEDERLANDS ABC VOOR HANDEL EN INDUSTRIE

\section{HSELINE \\ 1977-}

Health and safety aspects of manufacturing industries, agriculture, engineering, mining, etc.I

Reports, journals, books, proceedings, patents, standards
Health and Safety Executive

DS, S
(U.K.)
Abstracts and index to more than 4000 documents from the U.S. Housing and Urban Development Administration (HUD)/

Reports
U.S. Housing and Urban

B
HUD
Literature in such areas as language and literature, philosophy, performing arts, folklore, and history/

Journals
Development, Office of

Policy Development

\section{HUMANITIES INDEX} 1984
Directory and comprehensive information on companies in Scotland, England and Wales/

Financial data, directory information
H. W. Wilson Company

W

\section{ICC BRITISH COMPANY DIRECTORY \\ Current}

\section{ICC BRITISH COMPANY FINANCIAL DATASHEETS Current}

Commercial and financial information on 60,000 British companies/
Inter Company Comparisons Ltd. DS, L (U.K.)
Inter Company Comparison Ltd. DS, L (U.K.)

HUMANITIES INDEX 
ICC CANADIAN CORPORATION DATABASE

Current
Detailed profile, financial and performance information for the leading Canadian companies/

Financial data
ICC Canada Ltd. (U.K.)

DS
Detailed market information on 175 UK industry sectors/

\section{ANALYSIS}

Current

Reports

Detailed company and industry analysis from stockbrokers/
ICC Database (U.K.)

DS

KEYNOTE REPORTS

ICC STOCKBROKERS
RESEARCH
Current

\section{Reports}

ICIS-LOR OIL AND CHEMICAL REPORTS

Current
Pricing and background information for over 40 crude and 25 petroleum products/

Reports

\section{ICIS-LOR Group Ltd. (U.K.) DS \\ $S$}

DS

C Database (U.K.)

(U.K.)

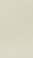


DATA BASE/ DATE

OF COVERAGE
DESCRIPTION/ PRINCIPAL SOURCES
PRODUCER/

HARD COPY

\section{INDEX TO LEGAL PERIODICALS 1981-}

Literature on all aspects of jurisprudence/

Journals, yearbooks, law reviews
H. W. Wilson Company

W
INDEX TO LEGAL PERIODICALS

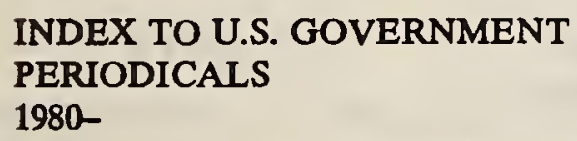

Subject access to over 185 journals published by the U.S. government/

Journals, proceedings, press conferences, letters, book reviews
Infordata International,

B, W

Incorporated

INDEX TO U.S. GOVERNMENT PERIODICALS

\begin{abstract}
INDUSTRY AND INTERNATIONAL STANDARDS Current
\end{abstract}

Voluntary engineering standards

Information Handling Services

B the U.S.; selected foreign standards \& major international standards/

Standards

Citations to market research reports, investment studies and statistical summaries/

Financial and economic reports, forecasts, directories, proceedings
Information Access Company

B, DS, L
Summaries of EPA regulations on particular industries and chemicals/

\section{DIRECTORY OF INDUSTRY DATA SOURCES}

\section{SYSTEM (IFIS)}

\begin{tabular}{l} 
INDUSTRY DATA SOURCES \\
$1979-$ \\
\hline \\
INDUSTRY FILE INDEX \\
SYSTEM (IFIS) \\
1985- \\
\\
\hline \\
INFORBW (INFORMATION \\
ABOUT RESEARCH IN THE \\
FEDERAL STATE OF BADEN- \\
WUERTTEMBERG) \\
1987-
\end{tabular}

\section{Regulations}

\author{
INFORBW (INFORMATION \\ ABOUT RESEARCH IN THE \\ FEDERAL STATE OF BADEN- \\ WUERTTEMBERG) \\ 1987-
}

Information in German concerning humanities, physical sciences, life sciences and

engineering/
U.S. Environmental Protection

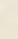
Agency

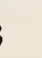




INFORMATION SCIENCE
ABSTRACTS
1966-

1966-
Worldwide coverage of infor- IFI/Plenum Data Company mation science literature/

Reports, proceedings, journals, patents, books
INFORMATION SCIENCE ABSTRACTS

INPADOC
Current
INSIDER TRADING MONITOR
1984

INPADOC

1984
Listing of worldwide patents

in all areas of technology/

Patents
International Patent

Documentation Center

INPADOC PATENT GAZETTE
L
Transaction details of all insider trading filings received by the SEC/
INVEST/NET

L
SEC financial data
L, S, STN
INSPEC

1969-
Worldwide coverage of the literature in physics, electrotechnology, computer and control engineering, and information technology/

Journals, technical reports, theses, proceedings, books, patents
Institution of Electrical Engineers

B, DS, L, S, STN
PHYSICS ABSTRACTS

(INSPEC A), ELECTRICAL AND ELECTRONIC ABSTRACTS (INSPEC B), COMPUTER AND CONTROL ABSTRACTS (INSPEC C), INFORMATION TECHNOLOGY (INSPEC D)

\section{INSURANCE ABSTRACTS 1979-1984}

Information on life and health insurance as well as risk management, property and liability insurance/

Journals
University Microfilms

L 
INTERAGENCY REHABILITA- Medical, psychological, educaTION RESEARCH INFORMATION tional, vocational and technical SYSTEM DATABASE 1981research data related to rehabilitation of handicapped individuals sponsored by U.S. government agencies/

Research data
Interagency Committee on Handi- B capped Research/National

Institute of Handicapped Research

\section{INTERNATIONAL PETROLEUM ABSTRACTS \\ 1984 \\ International literature on such areas as petroleum refining and products, geology, oilfield explor- ation and geophysics/ \\ Journals}

John Wiley and Sons

S

$\begin{array}{lll}\begin{array}{l}\text { INTERNATIONAL PHARMA- } \\ \text { CEUTICAL ABSTRACTS (IPA) }\end{array} & \begin{array}{l}\text { International literature on all } \\ \text { phases of drugs and pharma- } \\ \text { ceutical practices/ }\end{array} & \begin{array}{l}\text { American Society of Hospital } \\ \text { Pharmacists }\end{array} \\ & \text { Journals, reports } & \text { INTERNATIONAL PHARMA- } \\ & & \text { CEUTICAL ABSTRACTS }\end{array}$

INTERNATIONAL REVIEW OF PUBLICATIONS IN SOCIOLOGY 1980-
Citations to book reviews and detailed abstracts of books in sociology and related disciplines/

Books
Sociological Abstracts, Incorporated

B, DS, L

\section{CEUTICAL ABSTRACTS}

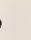


DATA BASE/ DATE

OF COVERAGE
DESCRIPTION/

PRINCIPAL SOURCES
PRODUCER/

HARD COPY
VENDOR
IRISH COMPANY PROFILES

Current
Information on 15,000 companies

from all sectors of the economy/
Institute of Industrial Research and Standards
L

Questionnaires
IRS TAXINFO

Current tax year
Entire text of the most frequently Internal Revenue Service

L requested IRS tax information publications/

IRS publications

IRS forms

IRSS (INFRARED SEARCH
SYSTEMS)
Current

IRSS (INFRA

Current
Information on 6500 IR spectra/

EPA/Boris Kidric Institute (Yugoslavia)
I

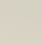




\begin{abstract}
JANE'S DEFENCE AND
AEROSPACE NEWS/ANALYSIS
JANE'S DEFENCE AND
AEROSPACE NEWS/ANALYSIS 1982-
\end{abstract}

International perspective on defense related topics/

Journals

General and business news from Japan and international news that relates to Japan/

Newswires
Jane's Information Group (U.K.)

L

JAPAN ECONOMIC NEWSWIRE
PLUS
1984

JAPAN 
DATA BASE/ DATE OF COVERAGE

KOMPASS UK

Current
DESCRIPTION/

PRINCIPAL SOURCES
PRODUCER/

HARD COPY
VENDOR
Directory of more than 110,000

companies in the U.K./

Directory information

Literature concerning the cosmetics and perfume industries/

KOSMET

1985-
Information Services Ltd.

(U.K.)

Various directory services
International Federation of the Society of Cosmetic Chemists (U.K.)
L

Reports, journals, proceedings

News of business activity in Japan/
Kyodo Service (Japan)

DS

RYODO JAP
SERVICE

Current

News data

LABORATORY HAZARDS

BULLETIN

1981-
Literature on hazards likely to be encountered by the chemical and biochemical laboratory research worker/

Journals, books, proceedings, audiovisual materials, press releases

\section{Royal Society of Chemistry} (U.K.)
DS

S

(n)


DATA BASE/ DATE

OF COVERAGE

LC (LIBRARY OF CONGRESS)

MARC

1968-
DESCRIPTION/

PRINCIPAL SOURCES
PRODUCER/

HARD COPY

VENDOR
Listing of monographic works of the Library of Congress/
U.S. Library of Congress

L, W
Monographs
1980-
Comprehensive index to legal
Information Access Company
and law related literature/
Journals, newspapers
LEGAL RESOURCE INDEX
(COM), CURRENT LAW INDEX
LEGAL STATUS
Listing of different types of
International Patent Documentation S actions which can affect the Center
legal status of a patent document
after it is published and granted/
Patent actions

LEXIS
1890 -(varies)
Full text of the law from the various courts in the U.S. and
Mead Data Central
in the U.K.; regulations/
Case law, slip opinions, slip laws, regulations
Caselaw Publications, FEDERAL
REGISTER, CODE OF FEDERAL REGULATIONS

B, L

\section{LIBRARY LITERATURE 1984}

Literature in library and information science/

Journals
H. W. Wilson Company

W

\section{LIBRARY LITERATURE}

Cambridge Scientific Abstracts

L

Worldwide research literature in the life sciences/

IRL Abstracting Journals

Journals, books, proceedings, patents

1978-
Worldwide literature on language and language behavior/

Journals, monographs
Sociological Abstracts,

Incorporated

B, L

\section{BEHAVIOR ABSTRACTS}

1973-
LINGUISTICS AND

LANGUAGE BEHLAVIOR

ABSTRACTS 
LISA (LIBRARY AND INFORMATION SCIENCE ABSTRACTS) 1969
Worldwide coverage of the literature of library and information science/

Journals, reports, monographs, proceedings
Learned Information (U.K.)

L, S SCIENCE ABSTRACTS

LIBRARY AND INFORMATION

\section{LITALERT}

1970-
Information related to unresolved or unreported cases against patents

INFAX Corporation

$\mathbf{S}$ and trademarks filed in the U.S.

District Courts/

Cases
M\&A FILINGS

1985-
Detailed abstracts of every original and amended merger and acquisition document released by the SEC/

Merger and acquisition filings
M\&A Filings, Charles E. Simon and Company
L

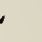

Full text of McGraw-Hill's leading magazines/
McGraw-Hill, Incorporated

$\mathbf{L}$

MCGRAW-HILL BUSINESS

BACKGROUNDER

1985-
Magazines

Complete text of current news stories covering top business events around the world/
L 1987-

News stories

McGraw-Hill Publications 


\section{DATA BASE/ DATE OF COVERAGE}

DESCRIPTION/

PRINCIPAL SOURCES
PRODUCER/

HARD COPY
VENDOR

$\begin{array}{ll}\begin{array}{l}\text { MANAGEMENT AND MARKET- } \\ \text { ING ABSTRACTS } \\ \text { 1976- }\end{array} & \begin{array}{l}\text { Worldwide literature of manage- } \\ \text { ment and marketing developments } \\ \text { in the fields of paper and board } \\ \text { manufacture (subset of PIRA)/ }\end{array} \\ & \text { Journals }\end{array}$ S

\section{MARQUIS WHO'S WHO} 1982-
Detailed biographical information on outstanding professionals in all fields/

Biographical data

Full text database on the properties of drugs and medicines/

Drug data
Marquis Who's Who Incorporated

\section{L}

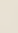

MARQUIS WHO'S WHO Series

The Pharmaceutical Society

DS, L of Great Britain

MARTINDALE, THE EXTRA PHARMACOPOEIA

American Society for Metals/

DS, L, S, STN

Worldwide literature on the commercial aspects of steels, non-ferrous metals, polymers, Institute of Metals
STEELS ALERT, NONFERROUS

ALERT, POLYMERS/CERAMICS/ COMPOSITES ALERT

$\begin{array}{lll}\begin{array}{l}\text { MATH } \\ 1972-\end{array} & \begin{array}{l}\text { Worldwide publications in } \\ \text { pure and applied mathematics/ }\end{array} & \begin{array}{l}\text { Fachinformationszentrum } \\ \text { Karlsruhe }\end{array} \\ & \text { Journals, proceedings, books } & \begin{array}{l}\text { ZENTRALBLATT FUR } \\ \text { MATHEMATIK }\end{array} \\ \begin{array}{l}\text { MATHSCI } \\ 1959-\end{array} & \begin{array}{l}\text { Worldwide literature on } \\ \text { mathematics/ }\end{array} & \text { American Mathematical Society } \\ & \text { Journals, books, proceedings } & \begin{array}{l}\text { MATHEMATICAL REVIEWS, } \\ \text { CURRENT INDEX TO STATISTICS, } \\ \text { INDEX TO STATISTICS AND }\end{array} \\ & & \text { PROBABILITY }\end{array}$


MDF/I

Current
Numerical information on all ferrous and mon-ferrous metals and alloys/
American Society for Metals

S

Data

MEDIA GENERAL DATABANK Current 5 years
Financial and stock trading information on 4300 public companies/

Reports, press releases, newswire services
Media General Financial Services

L
Access to current literature of clinical medicine and psychology

from about 160 core journals/

Journals
BRS/Saunders

B

\section{ICAL PREVIEWS}

Current 3 months
National Library of Medicine

B, DS, L, NLM

Worldwide coverage of the literature of the biomedical sciences/

Journals, monographs

\section{INDEX MEDICUS} mental iliness/

Journals, reports, proceedings, bouts
L

International literature on al aspects of mental health \&

IFI/Plenum Data Company

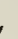
1969-
Factual information, critical reviews and reliability - validity information on English language tests covered in the MENTAL MEASUREMENTS YEARBOOK/
Buros Institute of Mental

B
YEARBOOK

1977-
Factual information
Measurements, University

of Nebraska

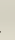

MEDLINE (MEDLARS-ON-L
1966-
MENTAL HEALTH ABSTRA
1969-
MENTAL MEASUREMENTS
YEARBOOK
1977-

Eighth MENTAL MEASUREMENTS YEARBOOK

L
Comprehensive information on computer programs for use with micro and minicomputers/

Computer programs
Imprint Editions Ltd.

\section{INTERNATIONAL SOFTWARE DIRECTORY}


DATA BASE/ DATE OF COVERAGE

DESCRIPTION/

PRINCIPAL SOURCES
PRODUCER/

HARD COPY

VENDOR
MERCK INDEX ONLINE

Current
Descriptions of substances of chemical, biological, pharmaceutical and commercial interests/

Monographs

International literature of metallurgy /

Journals, proceedings, books, reports
Merck \& Co., Incorporated

B, I, L
METADEX (METALS ABSTRACTS/ALLOYS INDEX) 1966-
MERCK INDEX

Materials Information

DS, L, S, STN

METALS ABSTRACTS INDEX, ALLOYS INDEX, REVIEW OF METAL LITERATURE

World wide literature of meteorological and geoastrophysical research/ GEOASTROPHYSICAL ABSTRACTS (MGA)

1972-
Journals, monographs, proceedings
American Meteorological Society

$\mathbf{L}$

\section{METEOROLOGICAL AND GEOASTROPHYSICAL ABSTRACTS}

MICROCOMPUTER INDEX

1981-
Literature on the use of microcomputers in business and in the home/
Learned Information, Incorporated

L

Journals

MICROCOMPUTER INDEX

Information on microcomputer software programs and hardware systems available or produced in the United States/

Press releases, books, periodicals
R. R. Bowker Company

$\mathbf{L}$

\section{AND HARDWARE GUIDE}

Current
THE SOFTWARE ENCYCLOPEDIA

$\begin{array}{ll}\text { MICROSEARCH } & \begin{array}{l}\text { Coverage of reviews and } \\ \text { instructional articles from } \\ \text { microcomputer-related } \\ \text { literature/ }\end{array} \\ & \text { Journals }\end{array}$

THE MIDDLE EAST: ABSTRACTS AND INDEX 1980-
News and literature of the Middle East/

Journals, reports, books, thesis
Northumberland Press

$\mathbf{L}$
Information, Incorporated

S 
MIDEAST FILE

1979
Coverage of the literature of history, demography, politics, government, etc. of Iran, Libya, Turkey, Sudan and other Mideast countries/

Journals, newspapers, books, reports
Learned Information (U.K.)

L
Listing of active and historical standards and specifications of the DOD and the federal government/

Standards
Information Handling Services

B

\section{SPECS AND STANDARDS}

Current/historical
MIDEAST FILE

MILITARY SPECIFICATIONS

AND STANDARDS, MILITARY

STANDARD DRAWINGS, HOT

SPECS

Comprehensive information covering modern language and literature/

Journals, books

\section{Modern Language Association L, W} of America

MLA BIBLIOGRAPHY
MOODY'S CORPORATE NEWS INTERNATIONAL 1983-
Financial and business information on more than 3900 major corporations and institutions in 100 countries/

Financial data
Moody's Investor's Service, Incorporated

L MOODY'S INTERNATIONAL NEWS REPORTS
MOODY'S CORPORATE, NEWSU.S. 1983-
Financial and business information on 13,000 publicly held U.S. corporations/

Financial data
Moody's Investor's Service, Incorporated

Various Moody's News Reports
L

Moody's Investors Service,

L

\section{MOODY'S CORPORATE PROFILES}

Current
Descriptive and financial information on the most important publicly held U.S. companies/
Incorporated
Financial data 
DATA BASE/ DATE

OF COVERAGE

MSDS (MATERLAL SAFETY

DATA SHEETS)

Current
DESCRIPTION/

PRINCIPAL SOURCES

Safety data on 1500 chemicals/

Occupational Health Services,

Incorporated
VENDOR

Chemical data

MSSS (MASS SPECTRAL

SEARCH SYSTEM)

1966-
Mass spectra for over 42,227 different substances/
National Institutes of Health

(NIH), Environmental Protection

Agency (EPA), Department of Industry (U.K.), National

Institute of Standards and

Technology (NIST)

Data

\section{NARIC (NATIONAL REHAB- ILITATION INFORMATION CENTER)}

1956-
Literature on the rehabilitation of the physically or mentally disabled/
National Rehabilitation

B

Information Center, Catholic

I

I

University of America

Reports, books, audiovisuals, microfiche

NASA/RECON

1962-
Worldwide literature in the fields of engineering, geosciences, mathematical and computer sciences, chemistry and materials, aeronautics and physics/

Reports, books, journals, patents
U.S. National Aeronautics and Space Administration

NASA
SCIENTIFIC AND TECHNICAL AEROSPACE REPORTS, INTERNATIONAL AEROSPACE ABSTRACTS
NATIONAL ENVIRONMENTAL DATA REFERRAL SERVICE Current
Catalog and index to nonbibliographic environmental data/

Data compilations, manuals, data centers, published and unpublished data files
National Oceanic and Atmospheric B Administration (NOAA)
Comprehensive coverage of The Foundation Center
L
NATIONAL FOUNDATIONS
Current
private foundations in the U.S./
$L$
Reports 
NATIONAL NEWSPAPER INDEX 1979.
Index to articles in major newspapers/

Newspapers
Information Access Company

B, L

NATIONAL NEWSPAPER INDEX (COM)
NCJRS (NATIONAL CRIMINAL International literature of criminal JUSTICE REFERENCE SERVICE) justice and law enforcement/ 1972-

Journals, reports
National Criminal Justice

L Reference Service

\begin{tabular}{|c|c|}
\hline $\begin{array}{l}\text { News and editorial information } \\
\text { from the NEW YORK TIMES } \\
\text { plus other newspapers and } \\
\text { magazines/ }\end{array}$ & New York Times Company \\
\hline Journals, newspapers & NEW YORK TIMES \\
\hline $\begin{array}{l}\text { Daily update of MAGAZINE } \\
\text { INDEX, NATIONAL NEWS- } \\
\text { PAPER INDEX, LEGAL } \\
\text { RESOURCE INDEX, TRADE } \\
\text { AND INDUSTRY INDEX and } \\
\text { MANAGEMENT CONTENTS/ }\end{array}$ & Information Access Company \\
\hline
\end{tabular}

NEW YORK TIMES 1969.

Newspapers, journals

\section{NEWSEARCH}

Current
Full text of newsletters represent- Newsnet ing 35 industry areas/

Newsletters

\section{NEWSNET}

Coverage varies
Index to articles from 19 major regional, national, and international newspapers/

Newspapers
University Microfilms International L 1984
Full text retrieval service for the news and scientific, technical, business and popular literature/

Magazines, newswires, newspapers, newsletters
$\mathrm{N}$

\section{Various newspapers}


NIMH (NATIONAL INSTITUTE

OF MENTAL HEALTH)

1969
International coverage of the mental health literature/
National Clearinghouse for Mental Health Information, National Institute of Mental Health

Journals, books, reports, proceedings

NMRLIT (NUCLEAR MAGNETIC RESONANCE LITERATURE SYSTEM)

1964-1984
Worldwide literature on nuclear magnetic resonance/
Preston Publications, Incorporated I

NONFERROUS METALS
ABSTRACTS
1961-1983

1961-1983
International literature on the nonferrous metals industry and the production and use of nonferrous metals/

Journals, books, pamphlets, reports, standards

Listing of condensed versions of NASA tech briefs/

Tech briefs
NUCLEAR MAGNETIC RESONANCE LITERATURE ABSTRACTS AND INDEX

\section{NTB (NASA TECH BRIEF) Current}

Government-sponsored research and development including sciences, technology, and regulatory matters/

Technical reports
BNF Metals Technology Centre

L

\section{NTIS}

1964
Comprehensive international information on nuclear science technology/

Journals, reports, proceedings, books, patents, thesis
National Technical Information Service

U.S. National Aeronautics and Space Administration (NASA)

NASA TECH BRIEFS
BNF NONFERROUS METALS ABSTRACTS

\section{NUCLEAR SCIENCE ABSTRACTS 1948-1976}

\section{WEEKLY GOVERNMENT \\ REPORTS, GOVERNMENT \\ REPORTS ANNOUNCEMENTS}

Department of Energy, Office

L of Scientific and Technical

Information

NUCLEAR SCIENCE

ABSTRACTS 
DATA BASE/ DATE OF COVERAGE

NURSING AND ALLIED

HEALTH

1983-
DESCRIPTION/

PRINCIPAL SOURCES
PRODUCER/

HARD COPY
VENDOR

B, DS, L
Broad coverage of the literature of nursing, allied health and health care/

Journals
Cumulative Index to Nursing and Allied Health Literature Corporation

CUMULATIVE INDEX TO NURSING AND ALLIED HEALTH LITERATURE
OAG ELECTRONIC EDITION Current
Flight information and fares for North American travel/
Official Airline Guide

$\mathbf{L}$

Travel information

\section{OCCUPATIONAL SAFETY AND HEALTH}

1973-
Literature on all aspects of the safety and heal th field/
National Institute for Occupational

L, S

Journals, reports

OCEANIC ABSTRACTS

1964
Worldwide literature on marinerelated subjects/

Journals, proceedings, books, reports
Cambridge Scientific Abstracts

L

OCEANIC ABSTRACTS

Descriptive information on books

OCLC, Incorporated

B, O

OCLC and serials added to the Library of Congress and about 7900 other libraries throughout the country/

Books, serials

Nonbibliographic data on oil and hazardous materials/
U.S. Environmental Protection

I Agency (EPA), Emergency Response Division
HAZARDOUS MATERIALS-

TECHNICAL ASSISTANCE

DATA SYSTEM)

Current
Safety and Heal th (NIOSH)

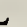

$\mathrm{s}$


DATA BASE/ DATE

OF COVERAGE
DESCRIPTION/

PRINCIPAL SOURCES
PRODUCER/

HARD COPY

VENDOR

Microcomputer software product Online, Incorporated

B

ONLINE MICROCOMPUTER SOFTWARE GUIDE AND

DIRECTORY (SOFT)

Current descriptions and related information/

Software packages
ONLINE MICRO-SOFTWARE GUIDE AND DIRECTORY

\section{ONTARIO EDUCATION RESOURCES INFORMATION DATABASE 1974-}

Index to materials produced or sponsored by the educational sectors in Ontario/
Ontario Ministry of Education (Canada)
B

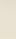




\section{PDR (PHYSICLANS' DESK REFERENCE) \\ Current}

Information on major pharma- Medical Economics Company, I ceutical and diagnostic products/ Incorporated
Drug data
DS, L, S

\section{P/E NEWS (PETROLEUM/ ENERGY BUSINESS NEWS INDEX) \\ 1975-}

International coverage of the literature of petroleum and

energy-related news items/

Journals
PHYSICIANS' DESK REFERENCE

American Petroleum Institute

I

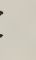

PETROLEUM/ENERGY BUSINESS NEWS INDEX
THE PESTICIDE DATABANK
Current

Data on more than 5000 chemical compounds and products/

Manufacturers data

PESTICIDE MANUAL

British Crop Protection Council

\section{PETERSON'S COLLEGE}

DATABASE

Current year
Comprehensive file of degreegranting, post-secondary colleges and universities in the U.S. and Canada/

Admission's Office data

$$
\text { Peterson's Guides, Incorporated }
$$

B, L

$B, L$

GUIDE TO FOUR-YEAR

COLLEGES, GUIDE TO

TWO-YEAR COLLEGES

PHARMACONTACTS

Current
Names and addresses of over 7,000 pharmaceutical companies in Europe and the Americas and 2,400 animal health companies worldwide/

Directories
V \& O Publications Ltd. DS (U.K.)
Various pharmaceutical and agrochemical directories

\section{PHARMAPROJECTS}

Current
Pharmaceutical products under development worldwide/

Drug information
PHARMLINE

1978-
Drug-related literature with emphasis on adverse drug effects/

Journals

Pharmaprojects, V \& O Publications Ltd. (U.K.)

PHARMAPROJECTS
Regional Drug Information

DS
DS Service (U.K.) 
DATA BASE/ DATE OF COVERAGE
DESCRIPTION/

PRINCIPAL SOURCES

Worldwide patents related to

Chemical Abstracts Service

STN

drugs and pharmaceutical

chemistry/

Patents

\section{PHILOSOPHER'S INDEX}

1940-
Comprehensive information on all aspects of philosophy and related fields/

Journals, books
Philosophy Documentation

Center

PHILOSOPHER'S INDEX
L

V \& O Publications Ltd. DS (U.K.)

developments, markets and regulatory affairs of importance to the international pharmaceutical, medical device, veterinary and agrochemical industries/

Newsletters
Various pharmaceutical and agrochemical newsletters
PHYSICS BRIEFS

1979-
Worldwide literature on all fields of physics and related topics/

Journals, proceedings, books, reports
Fachinformationszentrum (Germany)

\section{PHYSICS BRIEFS/} PHYSIKALISCHE BERICHTE

STN

University of Oklahoma,

I

Information on the biological effects of the application of organic chemicals to terrestrial plants/

Journals, data
Department of Botany and Microbiology
Current

PIRA

1975-
Worldwide literature in the fields The Research Association for of paper and board manufacturing, the Paper and Board, Printing printing, packaging, etc./ and Packaging Industries (PIRA) (U.K.)

Journals, books, pamphlets, standards
PAPER AND BOARD ABSTRACTS, PRINTING ABSTRACTS, PACKAGING ABSTRACTS, MANAGEMENT AND MARKETING ABSTRACTS

\section{$\mathbf{S}$}


PJB PHARMACEUTICAL INDUSTRY NEWS

Coverage varies
International newsletters reporting on pharmaceutical, device and diagnostic, veterinary and agrochemical industries/

Newsletters
PJB Publications Ltd. (U.K.)

DS

SCRIP; CLINICA; ANIMAL PHARM; AGROW
Current news about pharmaceuticals, cosmetics, medical devices/

Newsletters
Data Courier, Incorporated

L, S

\section{NEWS INDEX)}

1975-
FDC REPORTS, DRUG RESEARCH REPORTS, PMA NEWSLETTER, WASHINGTON DRUG AND DEVICE LETTER, etc.
B, DS, L

\section{POLLUTION ABSTRACTS} 1970-
Worldwide coverage of the literature of pollution and related topics/

Journals, technical reports, newspapers, government publications

\section{POLLUTION ABSTRACTS}

Literature in all areas of family planning, fertility control, population and reproduction/
Population Information Program, Johns Hopkins University/

Center for Population and

Family Health Library, Columbia

University

\section{NLM}

1970

Journals, monographs, reports, unpublished works

POPULAR MAGAZINE REVIEW ONLINE

1984-
Latest popular U.S. periodical literature/

Periodicals
Data Base Communications Corporation

B 
DATA BASE/ DATE

OF COVERAGE

POPULATION BIBLIOGRAPHY

1966-1984
DESCRIPTION/

PRINCIPAL SOURCES
PRODUCER/

HARD COPY
VENDOR
International coverage of population topics emphasizing the social science aspect/

Journals, monographs, reports, unpublished documents
Carolina Population Center,

L

at Chapel Hill

Catalog of books in the Depart- U.S. Department of Energy ment of Energy (DOE) Library/ (DOE), Library

Books, proceedings
POWER

1950
$S$
PR NEWSWIRE

1987-
PSYCHINFO

1967-
Worldwide literature of psych- American Psychological ology and the behavioral sciences/ Association

Journal, reports, monographs

PSYCHOLOGICAL ABSTRACTS

Index to defense industry

Predicasts, Incorporated

DS, L

\section{PTS AEROSPACE/DEFENSE} MARKETS AND TECHNOLOGY 1982-

information/
Complete text of news releases, mainly business and financial/
PR Newswire Association, Incorporated
News releases

\section{L}
B, DS, L

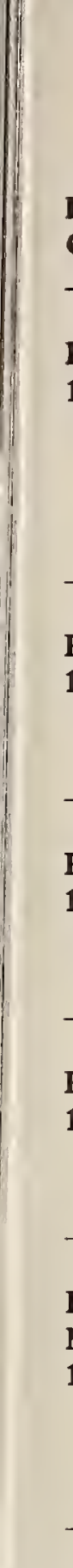

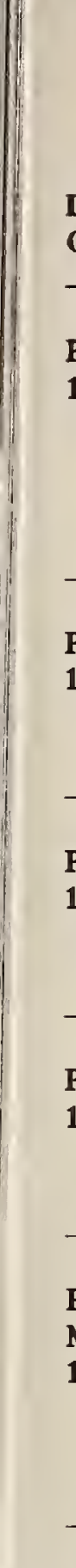
ABSTRACTS

Current

Journals, newspapers, reports, press releases, contract awards

Business information from annual reports/

Financial data, directory information
Predicasts Incorporated B, DS, L
PTS F+S INDEXES (FUNK AND SCOTT)

1972-1979
Domestic and international company, product, and industry information, such as new products, merges, forecasts of sales, etc./

Journals, reports, newspapers, bank letters
Predicasts, Incorporated B, DS, L

F + S INDEX OF CORPORATE

CHANGE, F+S INDEX

INTERNATIONAL, $F+S$ INDEX EUROPE

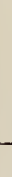


PTS FEDERAL INDEX

1976-
Selective information on federal Predicasts, Incorporated government activities/

Bills, rules, speeches, documents, FEDERAL INDEX reports
$\mathbf{L}$

Worldwide forecasts which in- Predicasts, Incorporated

$\mathrm{B}, \mathrm{DS}, \mathrm{L}$

PTS FORECASTS

1971-

clude market information, imports,

exports, prices, sales, etc./

Trade journals, business publica- PREDICASTS, WORLDCASTS

tions, newspapers, reports

Literature on marketing and advertising of consumer goods and services/
Predicasts, Incorporated

DS, L
ADVERTISING REFERENCE

SERVICE (MARS)

1984

Journals, newsletters, newspapers

PTS NEW PRODUCT

ANNOUNCEMENTS

1985-
Full text of news releases issued directly by companies on new products/

News releases
Predicasts, Incorporated

DS, L
PTS PROMT (PREDICASTS OVERVIEW OF MARKETS AND TECHNOLOGY) 1972
Data on products and services of the chemical, computer, communPredicasts, Incorporated

B, DS, L

Newspapers, reports, journals

PTS TIME SERIES

Coverage varies

\begin{abstract}
Annual data on U.S. production, wages, prices, etc., for all types of industries, products, and services as well as forecasts for key economic, demographic, industrial, and product time series/
\end{abstract}

Reports, studies
Predicasts, Incorporated
B, DS, L 
DATA BASE/ DATE

OF COVERAGE
DESCRIPTION/ PRODUCER/

PRINCIPAL SOURCES HARD COPY
VENDOR
PUBLISHERS, DISTRIBUTORS AND WHOLESALERS

Current
Information on the U.S. book publishing industry/

Directory information
R. R. Bowker Company

L

PUBLISHERS, DISTRIBUTORS

AND WHOLESALERS OF THE

U.S.
RAPRA ABSTRACTS

1972-
Index to the world's polymer literature/

Journals, proceedings, books, reports, patents
RAPRA TRÄDE NAMES 1976-
Trade names of interest to companies producing, supplying and using rubber and plastic materials and products/

Journals
Rubber and Plastics Research Association (U.K.)

RAPRA ABSTRACTS
RAPRA Technology Ltd. (U.K.) S

S 
REMARC (RETROSPECTIVE

MACHINE READABLE

CATALOGING)

1897-1980
Listing of bibliographic records for works cataloged by the

Library of Congress/

Books, proceedings

\section{RESOURCES IN VOCATIONAL EDUCATION (RIVE) \\ 1976-}

Ongoing and recently completed research and development projects in vocational education/

Proposal abstracts and documents
National Center for Research

B

State University

PROJECTS IN PROGRESS;

CURRENT PROJECTS IN

VOCATIONAL EDUCATION;

RESOURCES IN VOCATIONAL

EDUCATION

Reuters U.S., Incorporated

L business and international news/

News stories

RILM ABSTRACTS

1972-
International coverge of the music literature/

Books, journals, reviews, dissertations, catalogs
Repertoire International de Literature Musicale

RILM ABSTRACTS
L

Literature in German on regional planning, town planning, housing, building construction and civil engineering/

Journals, books, proceedings, reports, non-conventional literature
Information Center for

STN Building Construction of the Fraunhofer Society 1976-

Chemical toxicity data for 90,000 substances/ EFFECTS OF CHEMICAI SUBSTANCES)

Current
U.S. National Institute for Occupational Safety and Health (NIOSH) OF CHEMICAL SUBSTANCES 
SAE (SOCIETY OF AUTOMOTIVE Worldwide literature gathered

ENGINEERS) GLOBAL MOBILITY from industry, government, and 1965academic sectors on self-propelled vehicles/

Journals, proceedings

Liability information and hazards which threaten man and his environment/

Journals, proceedings, reports, books, patents, theses
Cambridge Scientific Abstracts S

\section{SAFETY SCIENCE ABSTRACTS}

SAFETY

1981-
Chemical nomenclature and substructure data for over 348,000 substances/
Chemical Information Systems, Incorporated

\section{SANSS (STRUCTURE AND NOMENCLATURE SEARCH SYSTEM) \\ Current}

Data

SCAN-A-BID

1984
Information on development project opportunities in the third world/

Journals

Information and descriptions on educational programs, curriculum materials, etc./

Descriptive information on products and programs
Development Business Scan-a-Bid DS

DEVELOPMENT BUSINESS
SCHOOL PRACTICES INFORMATION FILE (SPIF) Current
BRS

B

\section{SCIENTIFIC AMERICAN MEDICINE}

Current
Full text coverge of current developments in chemical medicine/

Journals
Scientific American, Incorporated B

\section{SCIENTIFIC AMERICAN} MEDICINE

Multidisciplinary index to the literature of science and technology I

Journals
Institute for Scientific Information

DS, L, S

\section{SCISEARCH (SCIENCE \\ 1974}


SEDBASE

Current
Synopsis of significant adverse

drug reactions and interactions/

Reports
Excerpta Medica (Netherlands) DS

Information Handling Services

B

Information on semiconductor technology and numeric parameters/

Vendor data sheets

SEMICONDUCTOR PARAMETER RETRIEVAL

National Library of Medicine

NLM
SERLINE (SERIALS ON-LINE)

Current
Descriptive information about medical serials/

Serials held by major U.S. medical libraries/
SILICA

1968-
Bibliographic database containing reference from international scientific, technical and historical literature on ceramics, glass, refractories and composite materials/

Journals, books, proceedings, standards, patents, thesis
Fachinformationszentrum

STN (FRG)
Universitaet Karlsruhe (FRG)

STN
SITRAFO

1987-
Information in French and German on current projects at the University of Strasburg, France and Karlsruhe, FRG/

Research projects and Universite Louis Pasteur (FR)
Worldwide scientific and technical literature on all aspects of smoking, tobacco and tobacco use/

Journals, reports, books, patents, book reviews
Office of Smoking and Health, L Department of Health and Human Services

SMOKING AND HEALTH BULLETIN 
DATA BASE/ DATE OF COVERAGE

SOCIAL PLANNING/POLICY

AND DEVELOPMENT

ABSTRACTS

1979-
DESCRIPTION/

PRINCIPAL SOURCES
PRODUCER/

HARD COPY

VENDOR
Worldwide literature in social welfare, social planning and policy and social development/

Journals

Sociological Abstracts,

B Incorporated

SOCIAL PLANNING/POLICY

AND DEVELOPMENT

ABSTRACTS
SOCIAL SCIENCES INDEX

1984 social sciences/

International literature of the

Journals
H. W. Wilson Company

W

SOCIAL SCIENCES INDEX
SOCIAL SCISEARCH

1972-
Worldwide literature of the social Institute for Scientific Information sciences and humanities/

Journals
SOCIAL SCIENCES CITATION INDEX
SOCIAL WORK ABSTRACTS July 1977-
Literature on all aspects of social work including aging, alcoholism, drug abuse, crime, family and child welfare/

Journals, dissertations
National Association of Social

B

Workers, Incorporated

SOCIAL WORK RESEARCH AND ABSTRACTS

\section{SOCIETE GENERALE DE BANQUE 1979-}

Literature on banking, economics, monetary problems, financial markets, etc./
B, L

Journals

Societe Generale de Banque

DS (Belguim)

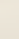

SOCIOLOGICAL ABSTRACTS

1963-
Worldwide literature in sociology and related disciplines/

Journals, monographs, theses, proceedings
Sociological Abstracts, Incorporated

SOCIOLOGICAL ABSTRACTS

Informationzentrum

Sozial wissenschaften (FRG)
B, DS, L

\section{SOLIS}

1945-
German language literature on the social sciences and their applications/

Journals, monographs 
SOVIET SCIENCE AND TECHNOLOGY

1975-
Scientific and technological infor- IFI/Plenum Data Company

L mation which is published in

Soviet Bloc countries/

Journals, patents, reports, proceedings
SPIN (SEARCHABLE PHYSICS INFORMATION NOTICES) 1975-
Worldwide coverage of the literature of physics, as well as astronomy, astrophysics, and geophysics/

Journals, proceedings of AIP

Literature in the areas of sports, recreation, sports medicine, and physical education/

Journals, books, theses
American Institute of Physics

(AIP)

L

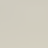

\section{SPORT \\ 1975-(periodicals) \\ 1949-(books)}

\section{Sport Information Research \\ Center (SIRC), Ontario, \\ Canada \\ SPORT AND RECREATION INDEX}

B, L
SSIE (SMITHSONIAN SCIENCE INFORMATION EXCHANGE) 1979-1982
Reports of government and privately funded scientific research projects/

Reports, on-going research
Smithsonian Science Information

Exchange, Incorporated

\section{NOTICE OF RESEARCH PROJECT}

L

Standard and Poor's Corporation

$\mathbf{L}$
STANDARD AND POOR'S NEWS June 1979
Information on companies including financial statements, sales, mergers/

Newspapers, reports, news releases, ticker services
CUMULATIVE NEWS, DAILY NEWS
Personal and professional data on business executives/
Biographical data

\author{
on business executives/
}

Biographical data
Standard and Poor's Corporation

L
REGISTER-BIOGRAPHICAL Current
STANDARD AND POOR'S REGISTER OF CORPORATIONS, DIRECTORS, AND EXECUTIVES

\section{STANDARD AND POOR'S} REGISTER-CORPORATE Current
Business and financial information on more than 8000 publicly-held

U.S. corporations/
Standard and Poor's Corporation

$\mathbf{L}$

Reports, press releases 
DATA BASE/ DATE OF COVERAGE
DESCRIPTION/

PRINCIPAL SOURCES
PRODUCER/

HARD COPY

VENDOR

National Standards Association L

Listing of all government and industry standards, specifications, and related documents/

Standards

Index to the Society of Automotive Engineers (SAE) and

the American Society for

Testing and Materials (ASTM)

standards/

Standards
SAE/ASTM

\section{Current}

STANDARDS AND
SPECIFICATIONS
Current

THE ANNUAL BOOK OF ASTM STANDARDS, THE SAE HANDBOOK, THE SAE AEROSPACE INDEX, THE SAE AMS INDEX OF AEROSPACE MATERIAL SPECIFICATIONS

\section{SUPERINDEX}

Current
Listing of back of the book index entries from major scientific reference publications/
Superindex, Incorporated

B

Books

SUPERTECH

1973-ROBOTS, BIOTECHNOLOGY 1984-AI, CAD/CAM
International literature on biotechnology, artificial intelligence, robotics, computer aided design, computer aided manufacturing and telecommunications/

Journals, proceedings, reports, books
Environmental Information

Center

L

TELEGEN REPORTER REVIEW, AI ABSTRACTS, CAD/CAM ABSTRACTS, ROBOMATIX REPORTER, TELECOMMUNICATION ABSTRACTS

\section{SURFACE COATINGS ABSTRACTS 1976-}

Worldwide coverage of the literature on all aspects of coatings applied to materials/

Journals, proceedings, books, patents
Paint Research Association 
SUSPECT (SUSPECT CHEMICALS SOURCEBOOK)

Current
Regulations and precautionary data on $\mathbf{4 0 0 0}$ chemical substances/

Roytech Publications,

Incorporated

Regulations, chemical data
SUSPECT CHEMICALS

SOURCEBOOK
SWISS LIBRARIES BIOMEDICAL JOURNALS

Current
Biomedical periodical publications held in Swiss libraries/

Secretariat RPM/VMZ

DS

(Switzerland)

Journals

TA (TECHNOLOGY

ASSESSMENT)

1975-
Literature in the field of technology assessment/
Kernforschungszentrum

Karlsruhe
STN

Reports, journals

Analytical summaries with the full text of all important legislative, regulatory, judicial and policy documents regarding federal taxation/

News stories, legislation, regulations, cases
Tax Notes Today

L
1987-
International literature of the textile industry/

Journals, reports, books, theses, patents
Institute of Textile Technology

$\mathbf{L}$ 1978-
Recommended values for selected thermodynamic properties for inorganic and simple organic substances/

Property values

\section{TEXTILE TECHNOLOGY} DIGEST

\section{THERMO}

Current
National Institute of Standards and Technology/Texas A\&M University, Thermodynamics Research Center

NIST TABLES OF CHEMICAL THERMODYNAMIC PROPERTIES/DATA FILES OF THE THERMODYNAMIC RESEARCH CENTER
THOMAS NEW INDUSTRIAL PRODUCTS

1985-
Information on new industrial products/
Thomas Publishing Company, Incorporated 
DATA BASE/ DATE
OF COVERAGE

THOMAS REGIONAL

INDUSTRIAL SUPPLIERS

1988
DESCRIPTION/

PRINCIPAL SOURCES
PRODUCER/

HARD COPY

VENDOR
Directory file of local manufacturers, distributors, manufacturer representatives and service companies with their products and services/
Thomas Regional Directory

Company/Thomas Online
L

Directory information

Information on what is made in the U.S., who makes it and where it is made/

Product and company information
Thomas Publishing Company

L
Current edition
Worldwide literature on textiles and related subjects/
Institut Textile de France

STN

\section{1-}

Journals, proceedings, patents, standards, books, reports

THOMAS REGISTER OF AMERICAN MANUFACTURERS

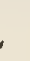


TRADE AND INDUSTRY INDEX 1981-
Trade, industry, and commerce related information/

Journals, newspapers, books, reports
Information Access Company

B, L
Information on all active registered and pending trademarks on file at the U.S. Patent and Trademark Office/
Thomson and Thomson

L

Trademarks

TRADEMARKSCAN-STATE

Current
Company and product information for trademarks registered in the states and Puerto Rico/
Thomson and Thomson

L

\section{TRINET COMPANY DATABASE} Current

Trademarks

Directory file providing address, financial and marketing information on U.S. single and multiestablishment companies/

U.S. Bureau of the Census statistics, reports, journals
Trinet, Incorporated

L
Directory file providing address, financial and marketing information on U.S. establishments with twenty or more employees/

U.S. Bureau of the Census statistics, reports, journals
Trinet, Incorporated

L

\section{DATABASE}

Current
Comprehensive information on highway, maritime, railroad, and air transportation/

Journals, ongoing research projects, reports
Transportation Research Board,

L

\section{RESEARCH INFORMATION} SERVICES)

1964-

\section{National Research Council}

HRIS ABSTRACTS, MRIS ABSTRACTS

\section{TROPAG}

1975-
International coverage of agriculture and related topics relevant to the tropics and subtropics/

Journals, theses, monographs, proceedings, reports
Koninklyk Instituut voorden

\section{ABSTRACTS ON TROPICAL AGRICULTURE}


TSCA CHEMICAL SUBSTANCES INVENTORY

Current
Compilation of chemical substances manufactured, imported or processed for commercial purposes in the U.S.I

Chemical substances
U.S. Environmental Protection Agency (EPA)

TOXIC SUBSTANCES CONTROL ACT (TSCA) CHEMICAL SUBSTANCE INVENTORY
TSCAPP (TOXIC SUBSTANCES CONTROL ACT PLANT AND PROTECTION DATA)

Current
References to non-confidential plant and production information for 55,000 chemical substances/
U.S. Environmental Protection Agency, Office of Pesticides and Toxic Substances

Reports, data

TSCATS (TOXIC SUBSTANCES CONTROL ACT TEST SUBMISSIONS)

Current
Unpublished health and safety studies submitted to EPA under the Toxic Substances Control Act/
Environmental Protection Agency I
$\mathbf{L}$

\section{I}

Studies

ULRICH'S INTERNATIONAL PERIODICALS DIRECTORY Current
Worldwide information on periodicals, serials, annuals, etc./
R. R. Bowker Company

B, L

Periodicals

ULRICH'S INTERNATIONAL PERIODICALS DIRECTORY, IRREGULAR SERIALS AND ANNUALS

Literature and ongoing projects concerning the environment/
(West Germany)
DS

Journals, books, research projects
UPI NEWS

April 1983-

Full text of news stories carried on the United Press International United Press International L wire/

News items

Comprehensive literature on all aspects of political science/
NASA Applications Center, University of Pittsburgh

\section{DOCUMENTS (USPSD)}

1975-
Journals

\section{U.S. POLITICAL SCIENCE DOCUMENTS}


DATA BASE/ DATE OF COVERAGE

USA TODAY DECISIONLINE

Most recent 2 weeks
DESCRIPTION/

PRINCIPAL SOURCES
PRODUCER/

HARD COPY

VENDOR
Concise news on the significant developments of the days top stories/

Newspaper

Classification information on patents issued by the U.S. Patent and Trademark Office/

Patents
Gannett News Media

L

USA TODAY

Derwent Publications Ltd.
S
(U.K.) 1790

All information found on the front page of a U.S. patent plus full claims information/

Patents
Derwent Publications Ltd. (U.K.)
1970

(U.S. PATENT ALERT)
Information in German on teaching and research institutions and their staff in the Federal Republic of Germany/

Directory information
Fachinformationszentrum STN

\section{VADEMECUM}

Current
Karlsruhe (F. R. Germany)

\section{VADEMECUM \\ DEUTSCHER LEHRUND \\ FORSCHUNGSSTAETTEN}

VEND

Current
Information from various vendor's

Information Handling Services

B catalogs in the areas of engineering, construction, transportation, etc./

Vendors catalogs

English language non-book materials on subjects of current interest in the humanities and social sciences/

Non-book materials
H. W. Wilson Company

w

\section{5-}

VERTICLE FILE INDEX 
VOCATIONAL EDUCATION CURRICULUM MATERIALS (VECM)

1977-
Current print and nonprint vocational education and technical curriculum materials/
National Center for Research in Vocational Education, Ohio State University
B

Books, audiovisuals

\section{VOLKSWAGENWERK}

1971-
Literature on automobile technology/
Volkswagenwerk (West Germany)
DS

Journals, proceedings, theses, books
VTB (VERFAHRENSTECHNISCHE Worldwide literature on chemical Bayer Ag BERICHTE)

1966- engineering in Germany/

STN

Journals, reports, books

\section{VU/TEXT}

Dates vary
Full text of major newspapers across the U.S.I

Newspapers
VU/TEXT Information Services, V Incorporated

Various Newspapers
WASHINGTON POST ELECTRONIC EDITION 1983-
Full text of the WASHINGTON Washington Post Company

L POST/

Newspaper

\section{WASHINGTON POST}

$\mathbf{L}$

\section{WATERNET}

1971-
Index to publications of the American Water Works Association and AWWA Research Foundation/

Reports, proceedings, books, journals
American Water Works Association

L

\section{Full text of official White House and U.S. Department of State news and policy information/ \\ Speeches, news conferences, interviews, etc. \\ Presstext News Service \\ WEEKLY COMPILATION OF PRESIDENTIAL DOCUMENTS; STATE DEPARTMENT BULLETIN \\ 1981-}


WELDASEARCH 1967-
Comprehensive literature covering all aspects of the joining of metals and plastics/
The Welding Institute (U.K.)

L

Journals, reports, books, patents, theses, standards

WHO MAKES MACHINERY Current
Listing of mechanical engineering products manufactured and offered for sale by about 4400 companies in Germany/
Hoppenstedt Wirtschafts Verlag

DS
Information on 51,000 German companies and their products/
Bezugsquellennachweis fur den

DS

WHO S
Current

Einkauf "wer liefert was?"

GmbH (West Germany) 


WORLD ALUMINUM
ABSTRACTS
1968-

ABSTRACTS

1968-
Technical literature on aluminum from ore processing (not mining) through end uses/

Journals, reports, proceedings, dissertations
American Society for Metals

L

WORLD ALUMINUM

ABSTRACTS
WORLD TEXTILES

1970-
World literature of textiles and the textile industry/

Journals, patents, standards, books, reports
Shirley Institute (U.K.)

L, S

WORLD TEXTILE

ABSTRACTS
Comprehensive international information relating to patents and patent specifications/

Patents
Derwent Publications, Ltd.

L, S 1963-

\section{CENTRAL PATENTS INDEX,} WORLD PATENTS INDEX

\section{WRA (WATER RESOURCES ABSTRACTS)} 1968-
Literature on water-related aspects of the life, physical, and social sciences/

Monographs, journals, reports
Water Resources Scientific Information Center, U.S.

Department of the Interior

SELECTED WATER

RESOURCES ABSTRACTS

\section{ZOOLOGICAL RECORD} 1978-
Coverage of the world's zoologi- BIOSIS cal literature with emphasis on systematic/taxonomic information/

Serials, theses, proceedings, journals
L

B, L 
Aerospace and Aeronautical Engineering

Agriculture and Agricultural Engineering

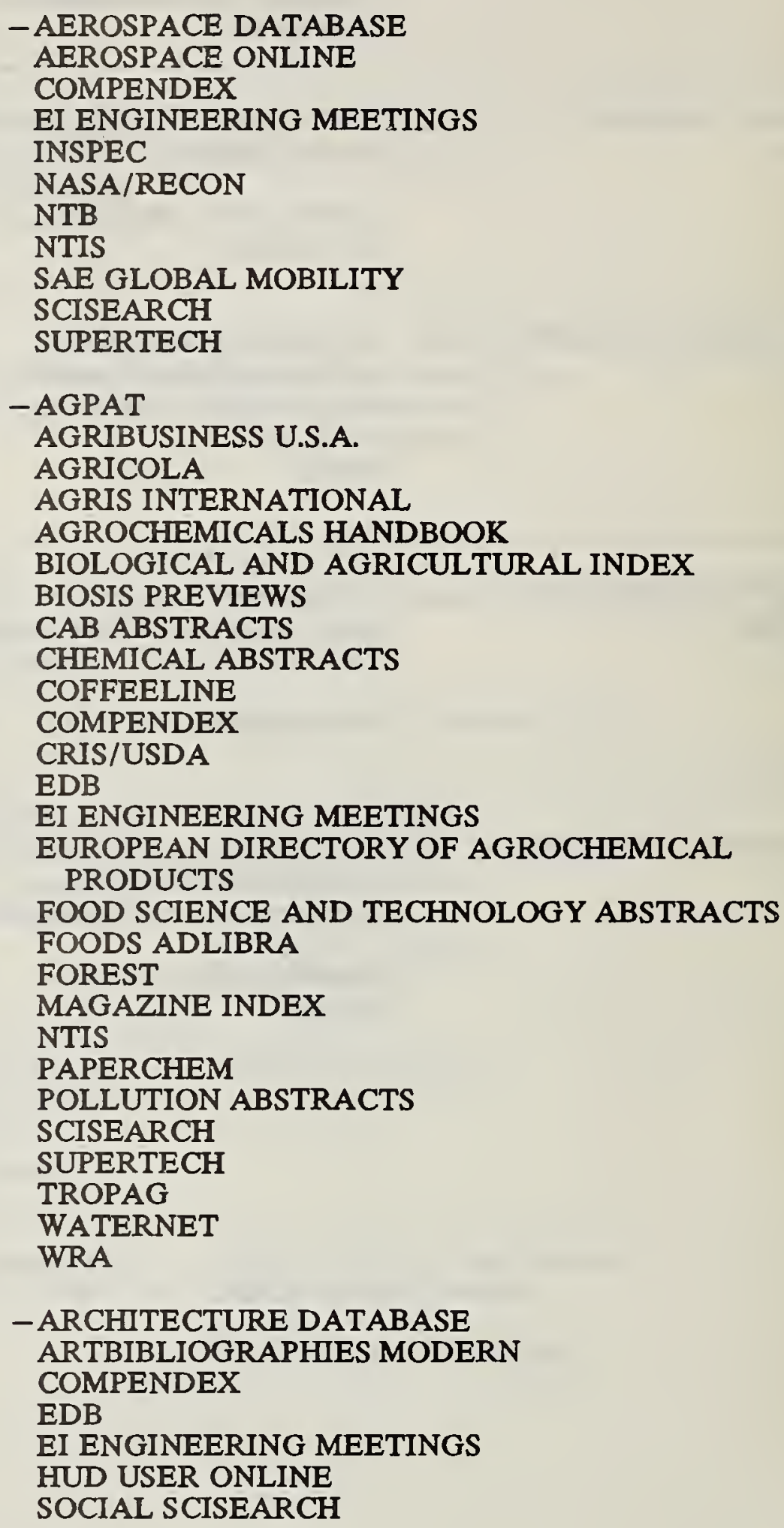


Arts and Humanities

Audiovisual Media

Bioengineering/Biotechnology

Biography

Biology

See: Life Sciences, Medicine

Buildings

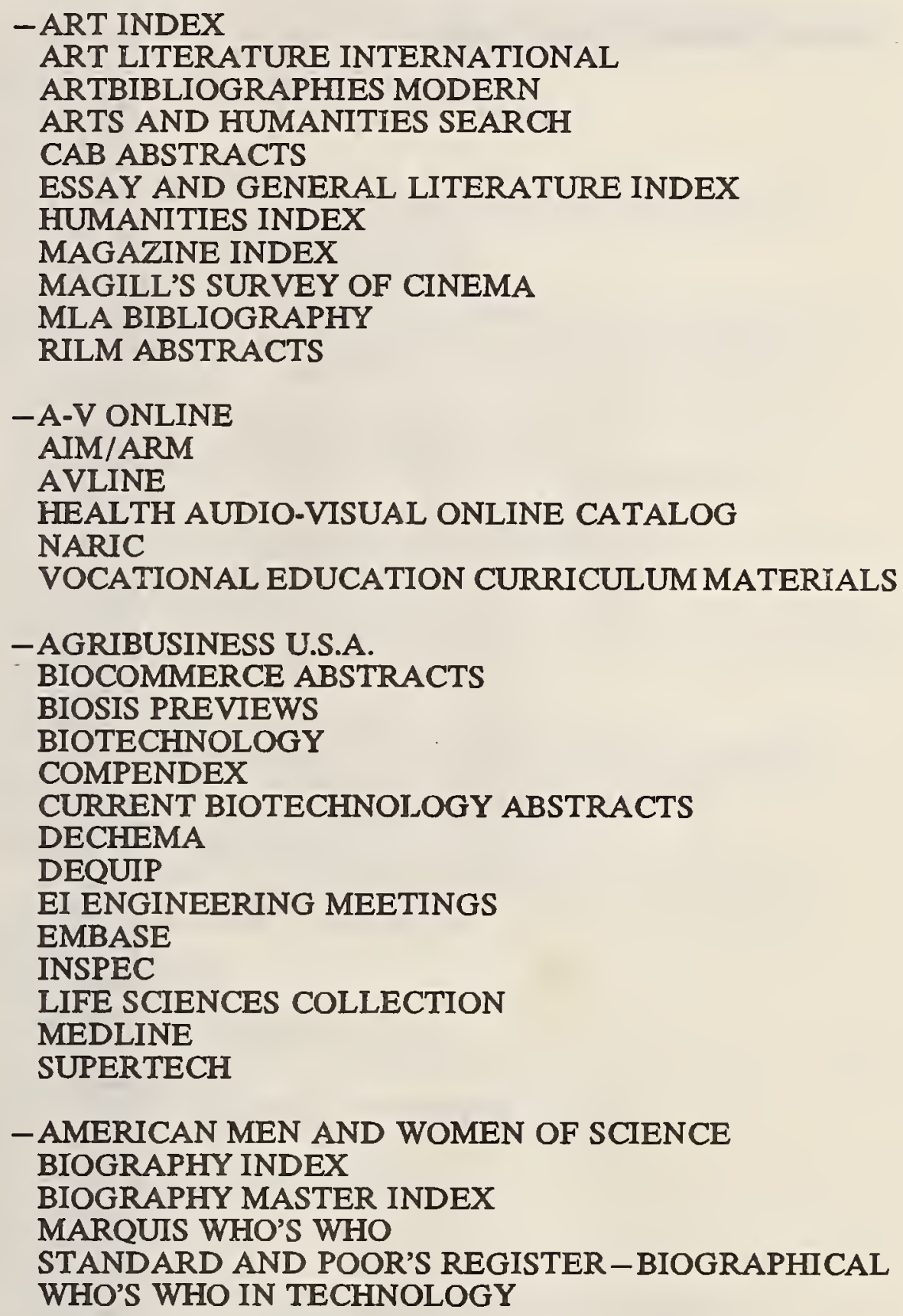

-AMERICAN MEN AND WOMEN OF SCIENCE BIOGRAPHY INDEX BIOGRAPHY MASTER INDEX MARQUIS WHO'S WHO STANDARD AND POOR'S REGISTER-BIOGRAPHICAL WHO'S WHO IN TECHNOLOGY

\section{- COMPENDEX}

EDB

EI ENGINEERING MEETINGS

FEDERAL RESEARCH IN PROGRESS

HUD USER ONLINE

ICONDA

NTIS

RSWB 
- ABC EUROPE ABC WEST GERMANY

ABI/INFORM

ABSTRACTS OF WORKING PAPERS IN ECONOMICS ACCOUNTANTS

AGRIBUSINESS U.S.A.

AIM/ARM

AMERICAN BANKER

ARTHUR D. LITTLE/ONLINE

BIOBUSINESS

BIOCOMMERCE ABSTRACTS

THE BOND BUYER

BUSINESS

BUSINESS AND INDUSTRY NEWS

BUSINESS DATELINE

BUSINESS OPPORTUNITIES

BUSINESS PERIODICALS INDEX

BUSINESS SOFTWARE DATABASE

BUSINESSWIRE

BUYERS' GUIDE-MEASUREMENT AND CONTROL CANADIAN BUSINESS AND CURRENT AFFAIRS

CAREER PLACEMENT REGISTRY

CATALYST RESOURCE ON THE WORKFORCE AND WOMEN

CHEMICAL BUSINESS NEWS BASE

CHEMICAL HAZARDS IN INDUSTRY

CIN

COMMERCE BUSINESS DAILY

CORPORATE AFFILIATIONS

CORPORATE AND INDUSTRY RESEARCH REPORTS ONLINE INDEX

D\&B - CANADIAN DUN'S MARKET IDENTIFIERS

D\&B - DUN'S ELECTRONIC YELLOW PAGES

D\&B - DUN'S FINANCIAL RECORDS

D\&B-DUN'S MARKET IDENTIFIERS

D\&B-INTERNATIONAL DUN'S MARKET IDENTIFIERS

D\&B - MILLION DOLLAR DIRECTORY

DIALOG QUOTES AND TRADING

DISCLOSURE FINANCIALS

DISCLOSURE MANAGEMENT

DISCLOSURE/SPECTRUM OWNERSHIP

ECON

ECON BASE: TIME SERIES AND FORECASTING

ECONOMIC LITERATURE INDEX

ELECTRONIC SELECTIVE ARCHIVES 
FEDERAL AND STATE BUSINESS ASSISTANCE FINANCIAL TIMES COMPANY ABSTRACTS

FINANCIAL TIMES FULLTEXT

FINDEX REPORTS AND STUDIES

FINIS

FOODS ADLIBRA

FOREIGN TRADE AND ECONOMIC ABSTRACTS

FOREIGN TRADERS INDEX

FOUNDATION DIRECTORY

FOUNDATION GRANTS INDEX

FROST \& SULLIVAN MARKET RESEARCH REPORTS

FROST \& SULLIVAN POLITICAL RISK COUNTRY

REPORTS

GERMAN COMPANY DATABASE

THE GERMAN INDUSTRY-MADE IN GERMANY GRANTS

HARFAX INDUSTRY DATA SOURCES

HARVARD BUSINESS REVIEW/ONLINE

HOPPENSTEDT AUSTRIA

HOPPENSTEDT DIRECTORY OF GERMAN COMPANIES

HOPPENSTEDT NETHERLANDS

HSELINE

ICC BRITISH COMPANY DIRECTORY

ICC BRITISH COMPANY FINANCIAL DATASHEETS

ICC CANADIAN CORPORATION DATABASE

ICC KEYNOTES MARKET ANALYSIS

ICC STOCKBROKERS RESEARCH

INDUSTRY AND INTERNATIONAL STANDARDS

INDUSTRY DATA SOURCES

INSPEC

INVESTEXT

INVESTOR'S DAILY

IRISH COMPANY PROFILES

IRS TAXINFO

JAPAN ECONOMIC NEWSWIRE PLUS

KOMPASS UK

KYODO NEW SERVICE

LABORDOC

LABORLAW

M\&A FILINGS

MCGRAW-HILL BUSINESS BACKGROUNDER

MCGRAW-HILL NEWS

MAGAZINE INDEX

MANAGEMENT AND MARKETING ABSTRACTS

MANAGEMENT CONTENTS

MEDIA GENERAL DATABANK

MOODY'S CORPORATE NEWS -INTERNATIONAL

MOODY'S CORPORATE NEWS-US

MOODY'S CORPORATE PROFILES 
DATA BASE NAME

Business, Economics, Management (cont.)

NATIONAL FOUNDATIONS

NEW YORK TIMES

$1 \times 1$ GERMAN BUYERS' GUIDE

PAIS INTERNATIONAL

P/E NEWS

PHARMACONTACTS

PIRA

PJB PHARMACEUTICAL INDUSTRY NEWS

PNI

PTS AEROSPACE/DEFENSE MARKETS AND

TECHNOLOGY

PTS ANNUAL REPORTS ABSTRACTS

PTS F\&S INDEXES

PTS FEDERAL INDEX

PTS FORECASTS

PTS MARKETING AND ADVERTISING REFERENCE SERVICE

PTS NEW PRODUCT ANNOUNCEMENTS

PTS PROMT

PTS TIME SERIES

REUTERS

SOCIAL SCISEARCH

SOCIETE GENERALE DE BANKE

STANDARD AND POOR'S CORPORATE DESCRIPTIONS

STANDARD AND POOR'S NEWS

THOMAS NEW INDUSTRIAL PRODUCTS

THOMAS REGISTER ONLINE

TRADE AND INDUSTRY INDEX

TRINET COMPANY DATABASE

TRINET ESTABLISHMENT DATABASE

WHO SUPPLIES WHAT

Chemistry and Chemical Engineering

-AEROSPACE DATABASE

AGRICOLA

AGROCHEMICALS HANDBOOK

AMERICAN CERAMIC ABSTRACTS

ANALYTICAL ABSTRACTS

APILIT

APIPAT

APTIC

AQUIRE

ASFA 


\section{GENERAL SUBJECT INDEX}

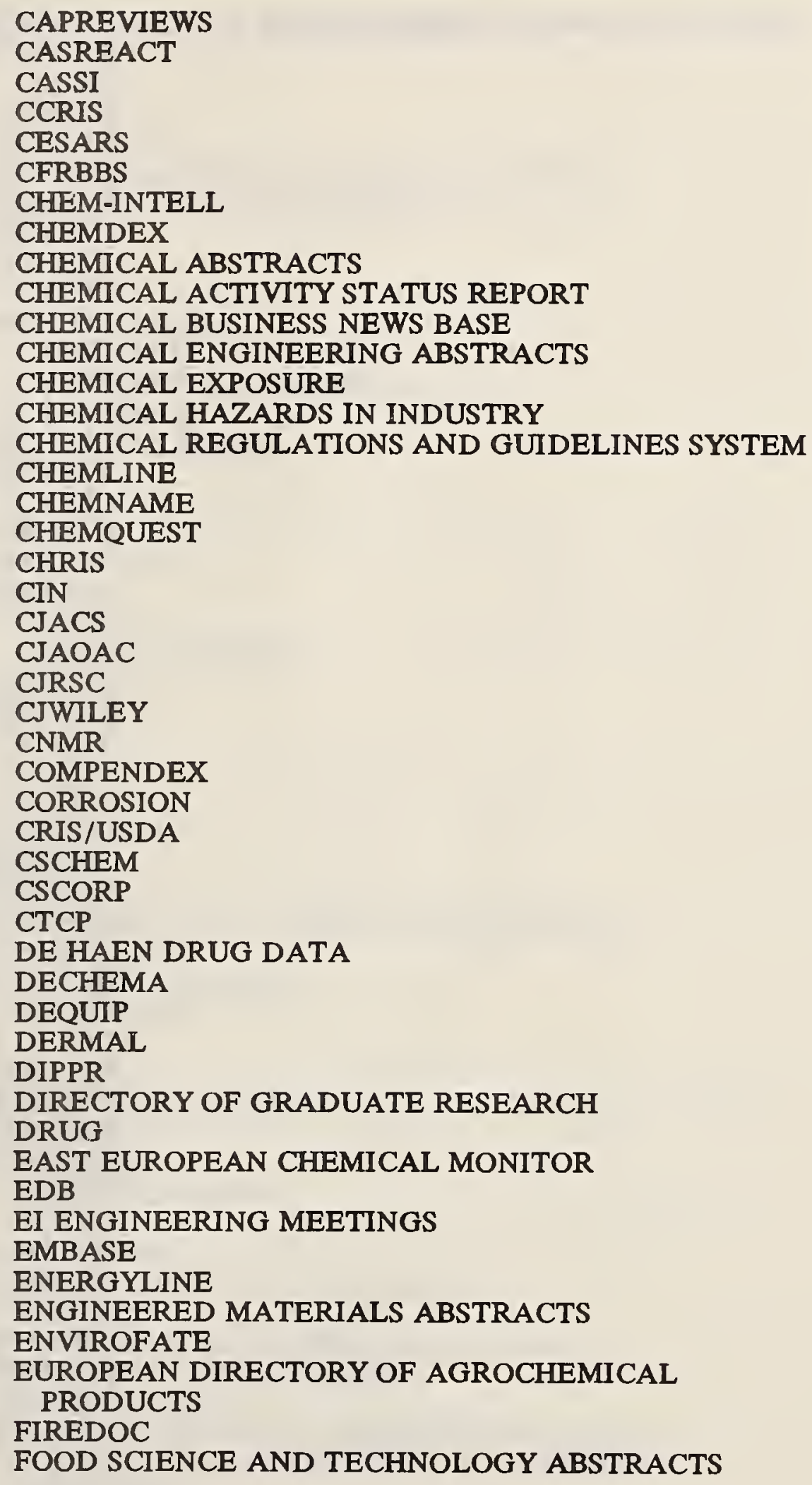


DATA BASE NAME

Chemistry and Chemical Engineering (cont.)

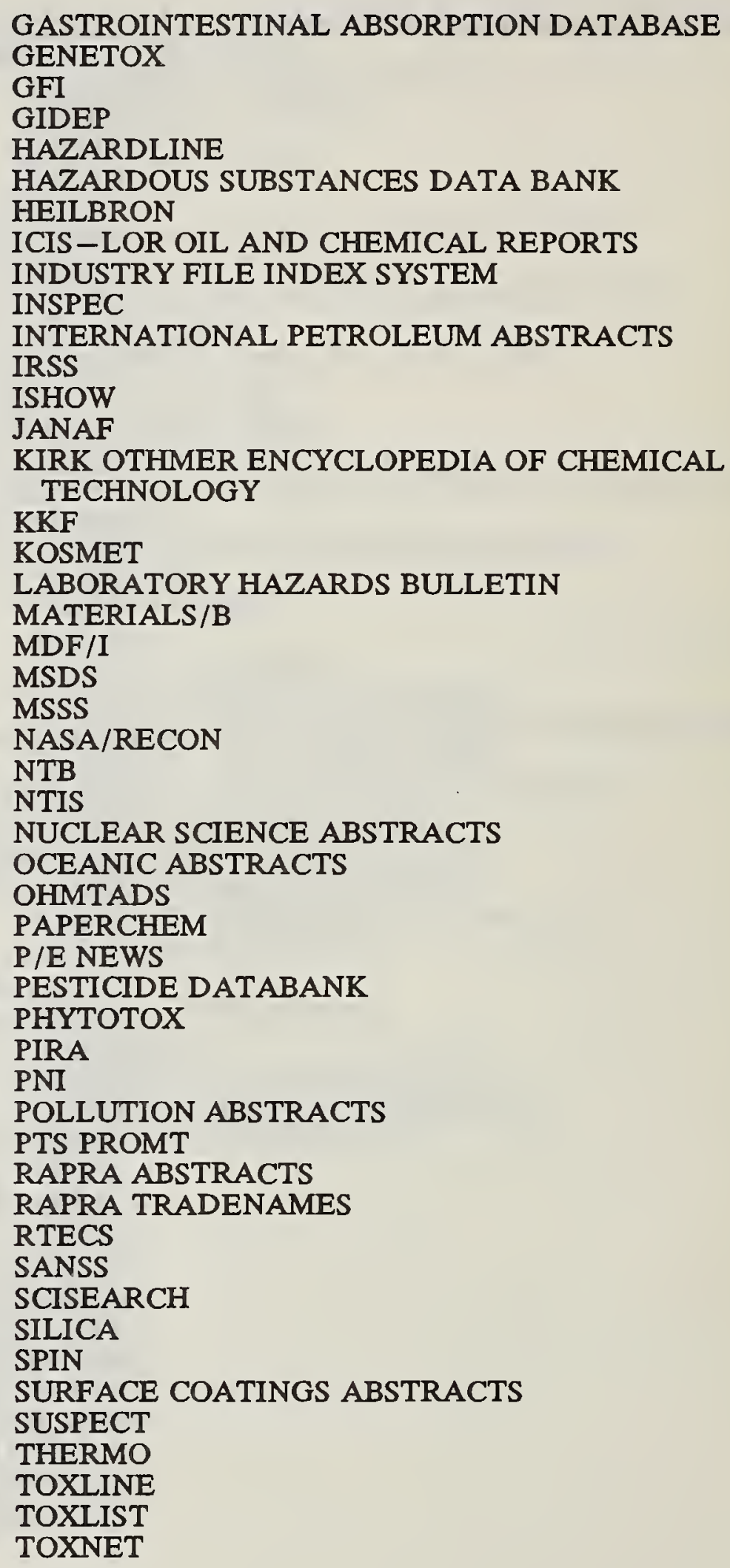


GENERAL SUBJECT INDEX

DATA BASE NAME

Chemistry and Chemical Engineering (cont.)

Civil Engineering

\section{-COLD REGIONS \\ COMPENDEX}

EI ENGINEERING MEETINGS

GEOARCHIVE

HUD USER ONLINE

ICONDA

INSPEC

ISMEC

NASA/RECON

NTB

NTIS

OCEANIC ABSTRACTS

RSBW

SCISEARCH

TRIS

WRA

Communications and Language

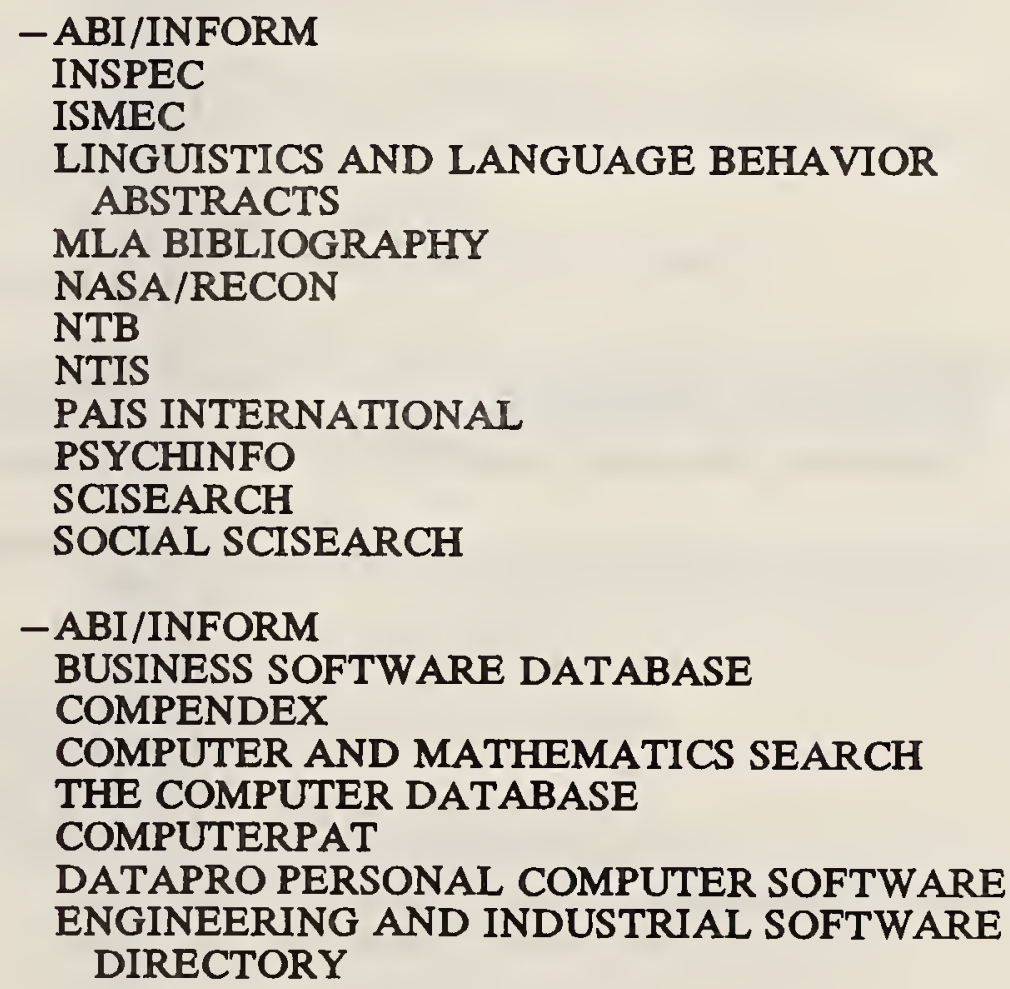

-ABI/INFORM

BUSINESS SOFTWARE DATABASE

COMPENDEX

COMPUTER AND MATHEMATICS SEARCH THE COMPUTER DATABASE

COMPUTERPAT

DATAPRO PERSONAL COMPUTER SOFTWARE

ENGINEERING AND INDUSTRIAL SOFTWARE DIRECTORY

Computer Science 


\section{GENERAL SUBJECT INDEX}

SUBJECT

Computer Science (cont.)

Cosmetics

Consumer Information

Current Research Projects

Earth and Space

See also: Aerospace and Aeronautical Engineering Mining and Metallurgy
DATA BASE NAME

INSPEC

ISIS

LISA

.MENU-THE INTERNATIONAL SOFTWARE

DATABASE

MICROCOMPUTER INDEX

MICROCOMPUTER SOFTWARE AND HARDWARE GUIDE

MICROSEARCH

NASA/RECON

NTB

NTIS

ONLINE MICROCOMPUTER SOFTWARE GUIDE AND

DIRECTORY

SCISEARCH

SUPERTECH

-KOSMET

-CONSUMER REPORTS

-AQUACULTURE

CHILD ABUSE AND NEGLECT

CLINPROT

CRIS/USDA

EPD

FBR

FEDERAL RESEARCH IN PROGRESS

FORIS

FORKAT

SITRAFO

SSIE

TRIS

UMWELTBUNDESAMT UMPLIS

-AEROSPACE DATABASE

AQUACULTURE

AQUALINE

ASFA

COLD REGIONS

ECON

EDB

FOREST

GEOARCHIVE

GEOBASE

GEOMECHANICS ABSTRACTS

GEOREF 
Earth and Space (cont.)

Economics

See: Business, Economics, Management

Education

Electronics and Electrical Engineering

See also: Civil Engineering

Mechanical Engineering
INSPEC

METEOROLOGICAL AND GEOASTROPHYSICAL ABSTRACTS

NASA/RECON

NTB

OCEANIC ABSTRACTS

SCISEARCH

SPIN

WATERNET

WRA

- AIM/ARM

AVLINE

CAREER PLACEMENT REGISTRY

D\&B ELECTRONIC DIRECTORY OF EDUCATION

DIRECTORY OF GRADUATE RESEARCH

ECER

ECON

EDUCATION INDEX

EDUCATIONAL TESTING SERVICE FILE

ERIC

GRADLINE

INTERAGENCY REHABILITATION RESEARCH

INFORMATION SYSTEM DATABASE

LINGUISTICS AND LANGUAGE BEHAVIOR ABSTRACTS

MENTAL MEASUREMENTS YEARBOOK

ONTARIO EDUCATION RESOURCES INFORMATION

DATABASE

PAIS INTERNATIONAL

PETERSON'S COLLEGE DATABASE

PSYCHINFO

RESOURCES IN VOCATIONAL EDUCATION

SCHOOL PRACTICES INFORMATION FILE

SOCJAL SCISEARCH

SPORT

VADEMECUM

VOCATIONAL EDUCATION CURRICULUM MATERIALS

-AEROSPACE DATABASE

COMPENDEX

THE COMPUTER DATABASE

EDB

EI ENGINEERING MEETINGS

ELECTRO/ELECTRONICS BUYERS' GUIDE

ELECTRONIC MATERIALS INFORMATION SERVICE

ELECTRONIC PUBLISHING ABSTRACTS

EPD

EPIA 


\section{GENERAL SUBJECT INDEX}

DATA BASE NAME

Electronics and Electrical Engineering (cont.)

Energy

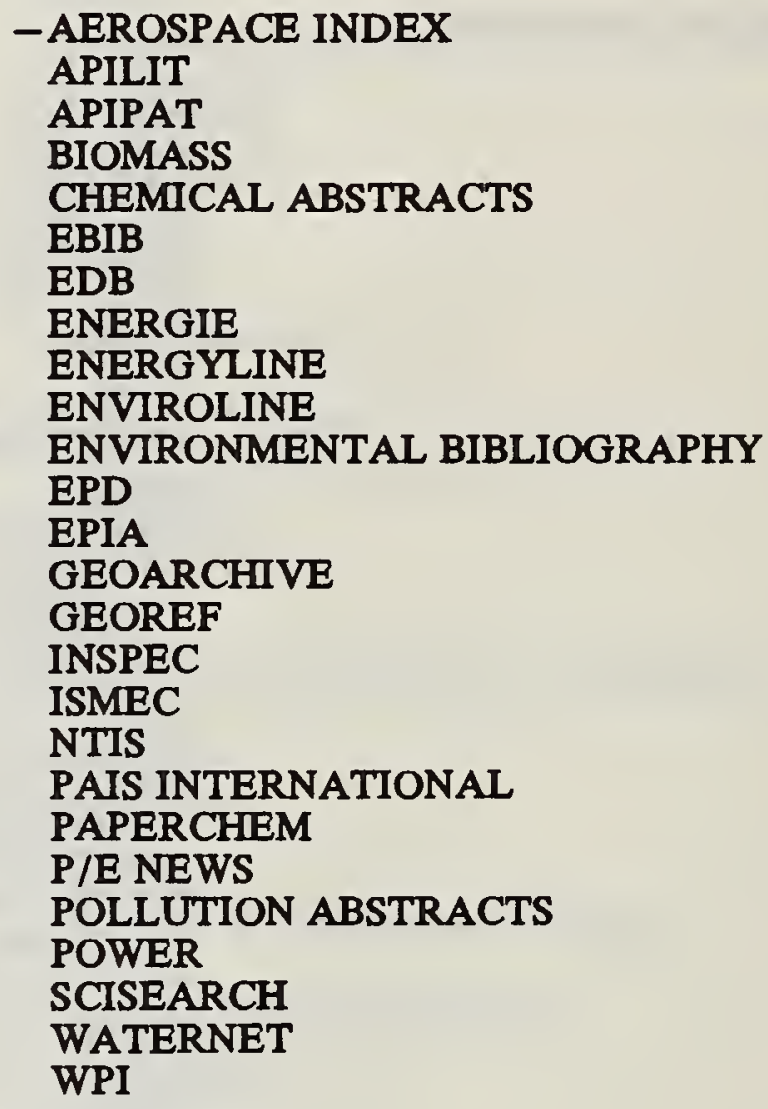

Engineering

See: Special Discipline of Engineering e.g., Civil Engineering, Mechanical Engineering, etc.

Environment

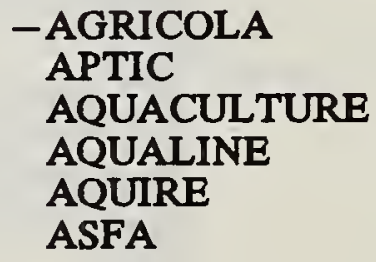


GENERAL SUBJECT INDEX

SUBJECT

Environment (cont.)

Food Science

See also: Agriculture and Agricultural Engineering

Forensic Science

Full Text Data Bases
DATA BASE NAME

BIOSIS PREVIEWS

CCRIS

CHEMICAL ABSTRACTS

COLD REGIONS

COMPENDEX

CONFERENCE PAPERS INDEX

DETEQ

EDB

EMBASE

ENERGYLINE

ENVIROFATE

ENVIROLINE

ENVIRONMENTAL BIBLIOGRAPHY

GEOARCHIVE

GEOBASE

GEOREF

ISHOW

MAGAZINE INDEX

MEDLINE

METEOROLOGICAL AND GEOASTROPHYSICAL ABSTRACTS

NATIONAL ENVIRONMENTAL DATA REFERRAL SERVICE

NTIS

OCEANIC ABSTRACTS

OHMTADS

PAPERCHEM

P/E NEWS

PHYTOTOX

POLLUTION ABSTRACTS

SCISEARCH

SOCIAL SCISEARCH

TRIS

UMWELTBUNDESAMT UMPLIS

WATERNET

WORLD ALUMINUM ABSTRACTS

WRA

-AGRICOLA

BIOSIS PREVIEWS

CHEMICAL ABSTRACTS

FOOD SCIENCE AND TECHNOLOGY ABSTRACTS

FOODS ADLIBRA

PACKAGING SCIENCE AND TECHNOLOGY ABSTRACTS

SCISEARCH

-FORENSIC SCIENCE DATABASE

-ACADEMIC AMERICAN ENCYCLOPEDIA AGRIBUSINESS U.S.A.

AIDS KNOWLEDGE BASE

AMERICAN BANKER

AP NEWS 


\section{GENERAL SUBJECT INDEX}

Full Text Data Bases (cont.)

BIBLE

THE BOND BUYER

BUSINESS DATELINE

BUSINESSWIRE

CJACS

CJAOAC

CJRSC

CJWILEY

COMMERCE BUSINESS DAILY

COMPREHENSIVE CORE MEDICAL LIBRARY

CONSUMER DRUG INFORMATION FULLTEXT

CONSUMER REPORTS

DIOGENES

DMS DEFENSE NEWSLETTERS

DRUG INFORMATION FULLTEXT

EVERYMAN'S ENCYCLOPEDIA

FINANCIAL TIMES FULLTEXT

GENERAL PRACTITIONER

HARVARD BUSINESS REVIEW

INVESTEXT

IRCS MEDICAL SCIENCE DATABASE

IRS TAXINFO

LEXIS

MCGRAW-HILL BUSINESS BACKGROUNDER

MCGRAW-HILL NEWS

MAGAZINE INDEX

MAGILL'S SURVEY OF CINEIMA

MARTINDALE ONLINE

NEW YORK TIMES

NEWSNET

NEXIS

OAG ELECTRONIC EDITION

PHIND

PR NEWSWIRE

PTS NEW PRODUCT ANNOUNCEMENTS

REUTERS

SCIENTIFIC AMERICAN MEDICINE

TAX NOTES TODAY

TOXNET

TRADE AND INDUSTRY INDEX

UPI NEWS

VU/TEXT

WASHINGTON POST ELECTRONIC EDITION WASHINGTON PRESSTEXT

General Science and Technology/Miscellaneous

-ACADEMIC AMERICAN ENCYCLOPEDIA APPLIED SCIENCE AND TECHNOLOGY INDEX ARTHUR D. LITTLE/ONLINE

ASI

ASSOCIATIONS PUBLICATIONS IN PRINT 
General Science and Technology/Miscellaneous (cont.)

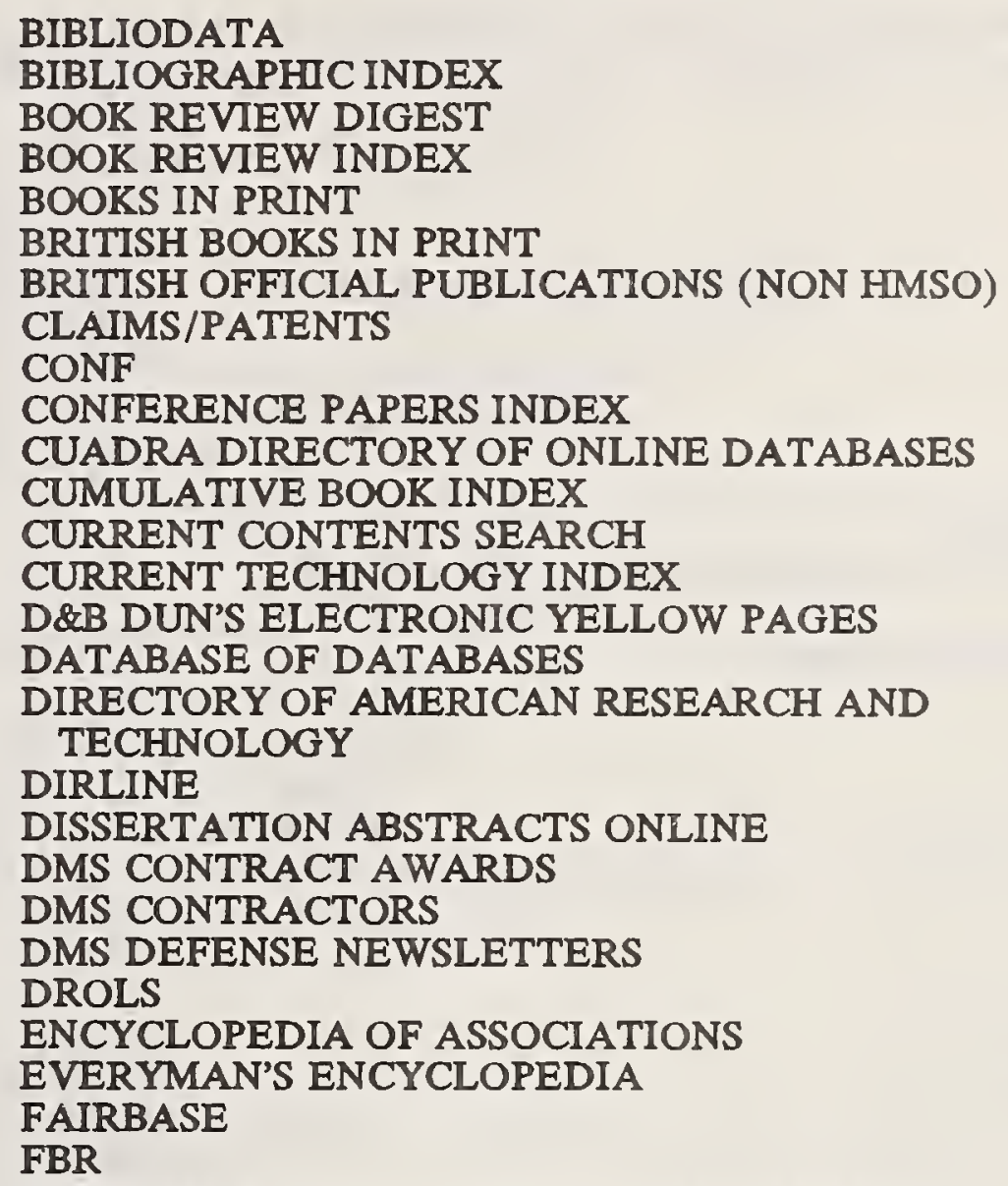


General Science and Technology/Miscellaneous (cont.)

Geology

See: Earth and Space Mining and Metallurgy

Government Reports

Grants

History

Information Science

Insurance

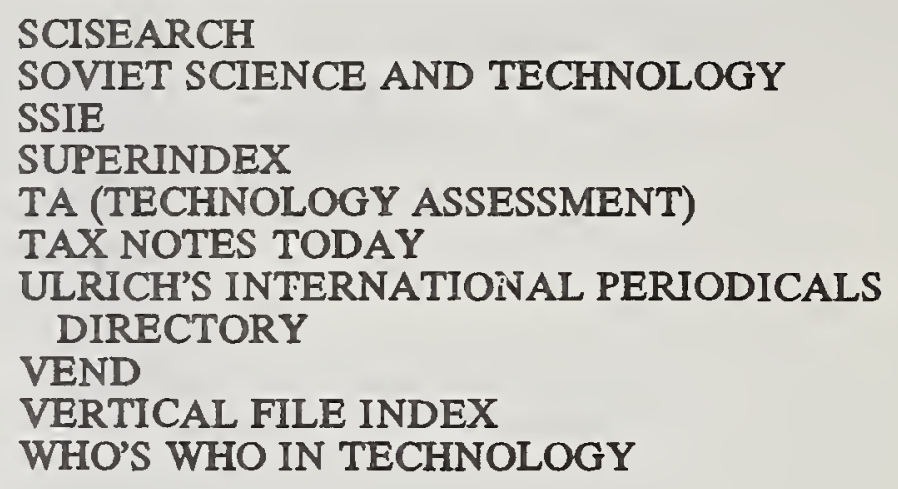

-INSURANCE ABSTRACTS 


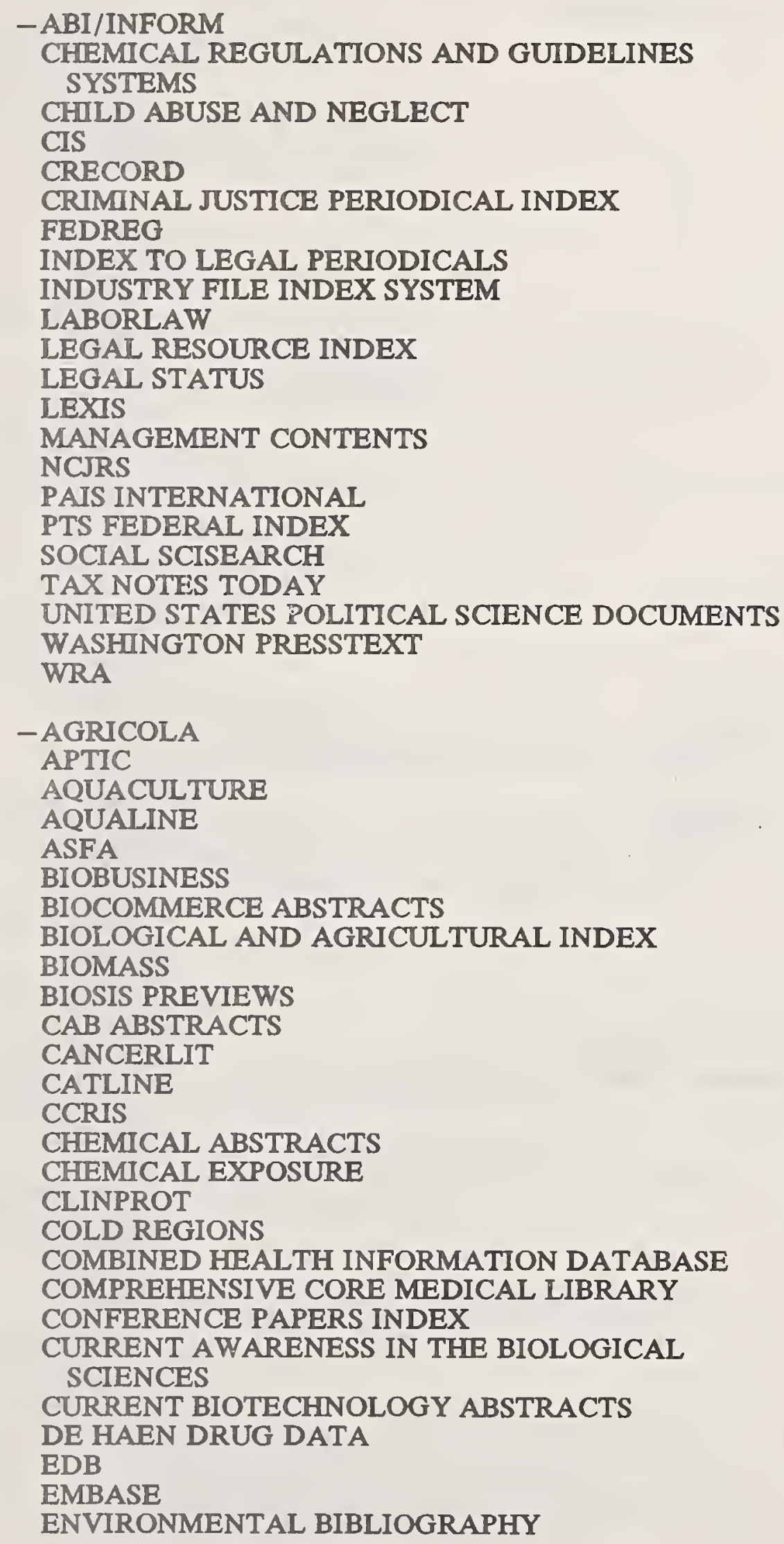


Life Sciences (cont.)

Literature

\section{Management}

See: Business, Economics, Management

Mathematics

Mechanical Engineering

See also: Electronics and Electrical Engineering

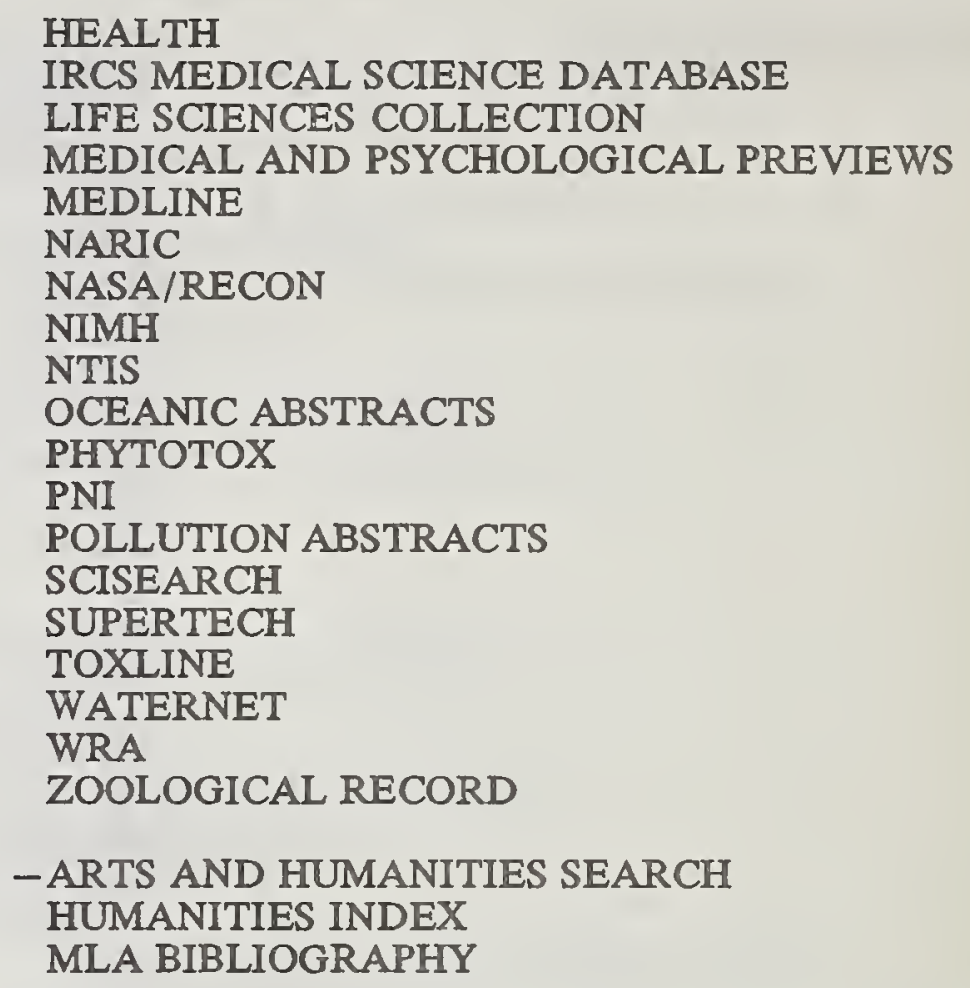


Mechanical Engineering (cont.)

SAE GLOBAL MOBILITY SCISEARCH

TRIS

VOLKSWAGENWERK

WHO MAKES MACHINERY

WPI

Medicine

See also: Life Sciences

- ABLEDATA

AGELINE

AIDS

AIDS KNOWLEDGE BASE

ALCOHOL INFORMATION FOR CLINICIANS AND EDUCATORS DATABASE

AVLINE

BIOBUSINESS

BIOCOMMERCE ABSTRACTS

BIOETHICS

BIOSIS PREVIEWS

BMA PRESS CUTTINGS

CAB ABSTRACTS

CANCERLIT

CATLINE

CCRIS

CHEMICAL EXPOSURE

CLINICAL ABSTRACTS

CLINICAL NOTES ONLINE

CLINPROT

COMBINED HEALTH INFORMATION DATABASE

COMPREHENSIVE CORE MEDICAL LIBRARY

CONSUMER DRUG INFORMATION FULLTEXT

CTCP

DE HAEN DRUG DATA

DERMAL

DHSS-DATA

DIOGENES

DRUG

DRUG INFORMATION FULLTEXT

EMBASE

ENVIRONMENTAL BIBLIOGRAPHY

GASTROINTESTINAL ABSORPTION DATABASE

GENERAL PRACTITIONER

GENETOX

HEALTH

HEALTH AUDIO-VISUAL ONLINE CATALOG

HEALTH INDUSTRY RESEARCH REPORTS

HISTLINE

HSELINE

IDIS DRUG FILE

INTERAGENCY REHABILITATION RESEARCH

INFORMATION SYSTEM DATABASE

INTERNATIONAL PHARMACEUTICAL ABSTRACTS

IRCS MEDICAL SCIENCE DATABASE 
GENERAL SUBJECT INDEX

SUBJECT

Medicine (cont.)
DATA BASE NAME

\section{JOURNAL WATCH}

MARTINDALE ONLINE

MEDICAL AND PSYCHOLOGICAL PREVIEWS

MEDLINE

MENTAL HEALTH ABSTRACTS

MERCK INDEX ONLINE

NARIC

NIMH

NTIS

NURSING AND ALLIED HEALTH

OCCUPATIONAL SAFETY AND HEALTH

PDQ

PDR

PHARIMA CONTACTS

PHARMA PROJECTS

PHARMLINE

PHARMPAT

PJB PHARMACEUTICAL INDUSTRY NEWS

PNI

PSYCHINFO

REHABDATA

SCIENTIFIC AMERICAN MEDICINE

SCISEARCH

SEDBASE

SERLINE

SMOKING AND HEALTH

SPORT

SUPERTECH

SWISS LIBRARIES BIOMEDICAL JOURNALS

TOXLINE

TOXNET

TSCATS

-BUYERS' GUIDE-MEASUREMENT AND CONTROL COMPENDEX

EI ENGINEERING MEETINGS

FLUIDEX

GIDEP

INDUSTRY AND INTERNATIONAL STANDARDS

INSPEC

ISMEC

MILITARY AND FEDERAL SPECS AND STANDARDS NONFERROUS METALS ABSTRACTS

NTIS

SCISEARCH

STANDARDS AND SPECIFICATIONS

STANDARDS SEARCH 


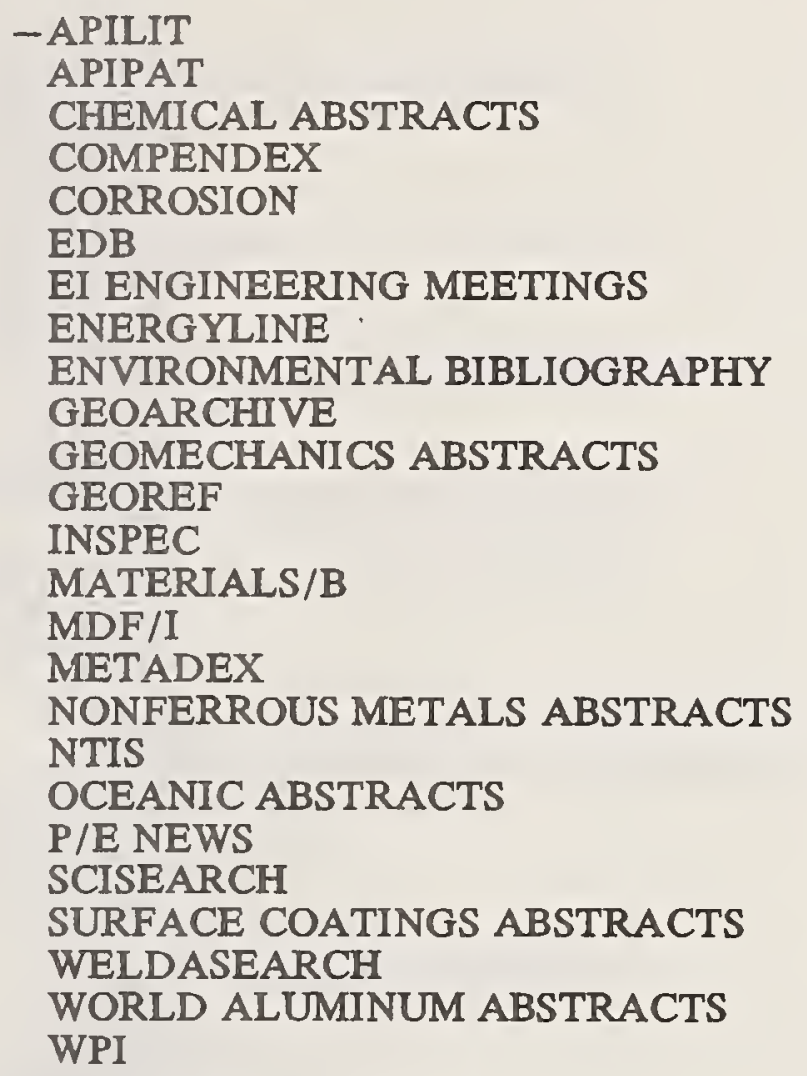

Music

-RILM ABSTRACTS

News

\author{
- AMERICA: HISTORY AND LIFE \\ AMERICAN BANKER \\ AP NEWS \\ BIOCOMMERCE ABSTRACTS \\ BMA PRESS CUTTINGS \\ THE BOND BUYER \\ BUSINESS AND INDUSTRY NEWS \\ BUSINESSWIRE \\ CANADIAN BUSINESS AND CURRENT AFFAIRS \\ CIN \\ ELECTRONIC SELECTIVE ARCHIVES \\ FACTS ON FILE \\ FINANCIAL TIMES COMPANY ABSTRACTS \\ FINANCIAL TIMES FULLTEXT \\ INVESTOR'S DAILY \\ KYODO NEWS SERVICE \\ MCGRAW-HILL NEWS \\ MAGAZINE INDEX \\ THE MIDDLE EAST: ABSTRACTS AND INDEX \\ MIDEAST FILE \\ NATIONAL NEWSPAPER INDEX \\ NEW YORK TIMES \\ NEWSEARCH \\ NEWSPAPER ABSTRACTS \\ NEXIS
}


PJB PHARMACEUTICAL INDUSTRY NEWS

PR NEWSWIRE

REUTERS

UPI NEWS

USA TODAY DECISIONLINE

VU/TEXT

WASHINGTON POST ELECTRONIC EDITION

WASHINGTON PRESSTEXT

WORLD AFFAIRS REPORT

Patents

- CHEMICAL ABSTRACTS

COMPENDEX

EDB

EI ENGINEERING MEETINGS

ENERGYLINE

GIDEP

INSPEC

NTIS

NUCLEAR SCIENCE ABSTRACTS

POLLUTION ABSTRACTS

SCISEARCH

SPIN

-AGPAT

APIPAT

CHINESE PATENT ABSTRACTS

CLAIMS/CITATION

CLAIMS/PATENTS

CLAIMS/REFERENCE

COMPUTERPAT

DEUTSCHE PATENT DATENBANK

INPADOC

JAPIO

LEGAL STATUS

LITALERT

PATDATA

PHARMPAT

TRADEMARKSCAN-FEDERAL

TRADEMARKSCAN-STATE

USCLASS

USPA

WPI

Philosophy

-PHILOSOPHER'S INDEX

SOCIAL SCISEARCH

Photography

-IMAGING ABSTRACTS

Physics

- AEROSPACE DATABASE CHEMICAL ABSTRACTS COMPENDEX 
Physics (cont.)

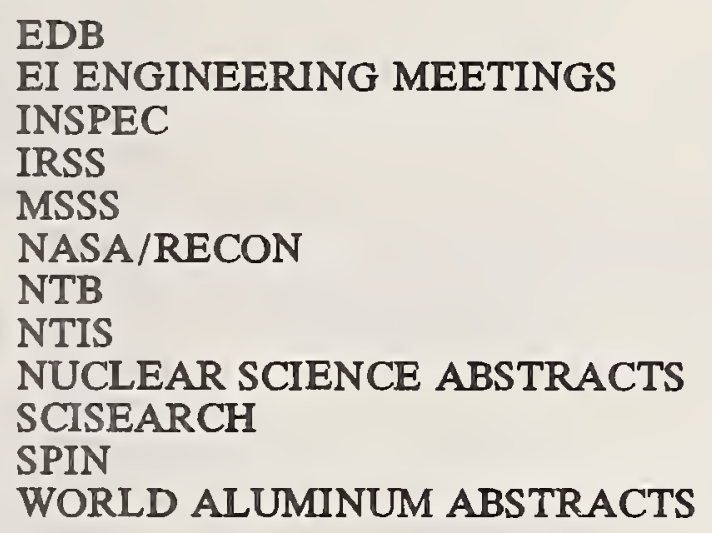

Psychology

- CHILD ABUSE AND NEGLECT

ECER

ECON

EMBASE

LINGUISTICS AND LANGUAGE BEHAVIOR ABSTRACTS

NIMH

PSYCHINFO

SOCIAL SCISEARCH

SOCIOLOGICAL ABSTRACTS

Public Administration

$-\mathrm{ABI} / \mathrm{INFORM}$

CIS

CRECORD

FEDREG

FROST \& SULLIVAN POLITICAL RISK COUNTRY REPORTS

MANAGEMENT CONTENTS

THE MIDDLE EAST: ABSTRACTS AND INDEX

MIDEAST FILE

PAIS INTERNATIONAL

PTS FEDERAL INDEX

SCAN-A-BID

SOCIAL SCISEARCH

UNITED STATES POLITICAL SCIENCE DOCUMENTS

WASHINGTON PRESSTEXT

WORLD AFFAIRS REPORT

Religion

-BIBLE

RELIGION INDEX

Safety

-DECHEMA

HSELINE

MSDS

OCCUPATIONAL SAFETY AND HEALTH

SAFETY 
- AGELINE
CATALYST RESOURCE ON THE WORKFORCE AND WOMEN

CHILD ABUSE AND NEGLECT

CRIMINAL JUSTICE PERIODICAL INDEX

DRUG

ECON

FAMILY RESOURCES

FORIS

HISTORICAL ABSTRACTS

INTERNATIONAL REVIEW OF PUBLICATIONS IN SOCIOLOGY

LABORDOC

LINGUISTICS AND LANGUAGE BEHAVIOR ABSTRACTS

THE MIDDLE EAST: ABSTRACTS AND INDEX MIDEAST FILE

NCJRS

PAIS INTERNATIONAL

POPLINE

POPULATION BIBLIOGRAPHY

PTS FEDERAL INDEX

RSWB

SOCIAL PLANNING/POLICY AND DEVELOPMENT ABSTRACTS

SOCIAL SCIENCES INDEX

SOCIAL SCISEARCH

SOCIAL WORK ABSTRACTS

SOCIOLOGICAL ABSTRACTS

SOLIS

SPORT

UNITED STATES POLITICAL SCIENCE DOCUMENTS

WORK/FAMILY LIFE DATABASE

Sports

- SPORT

Statistics

-ASI

CENDATA

DONNELLEY DEMOGRAPHICS

PTS F\&S INDEXES

PTS FORECASTS

PTS PROMT

PTS TIME SERIES

Textiles

- CHEMICAL ABSTRACTS

PAPERCHEM

TEXTILE TECHNOLOGY DIGEST

TITUSE

WORLD TEXTILES

WPI 
GENERAL SUBJECT INDEX

SUBJECT

Toxicology

Transportation and Utilities

Zoology

DATA BASE NAME

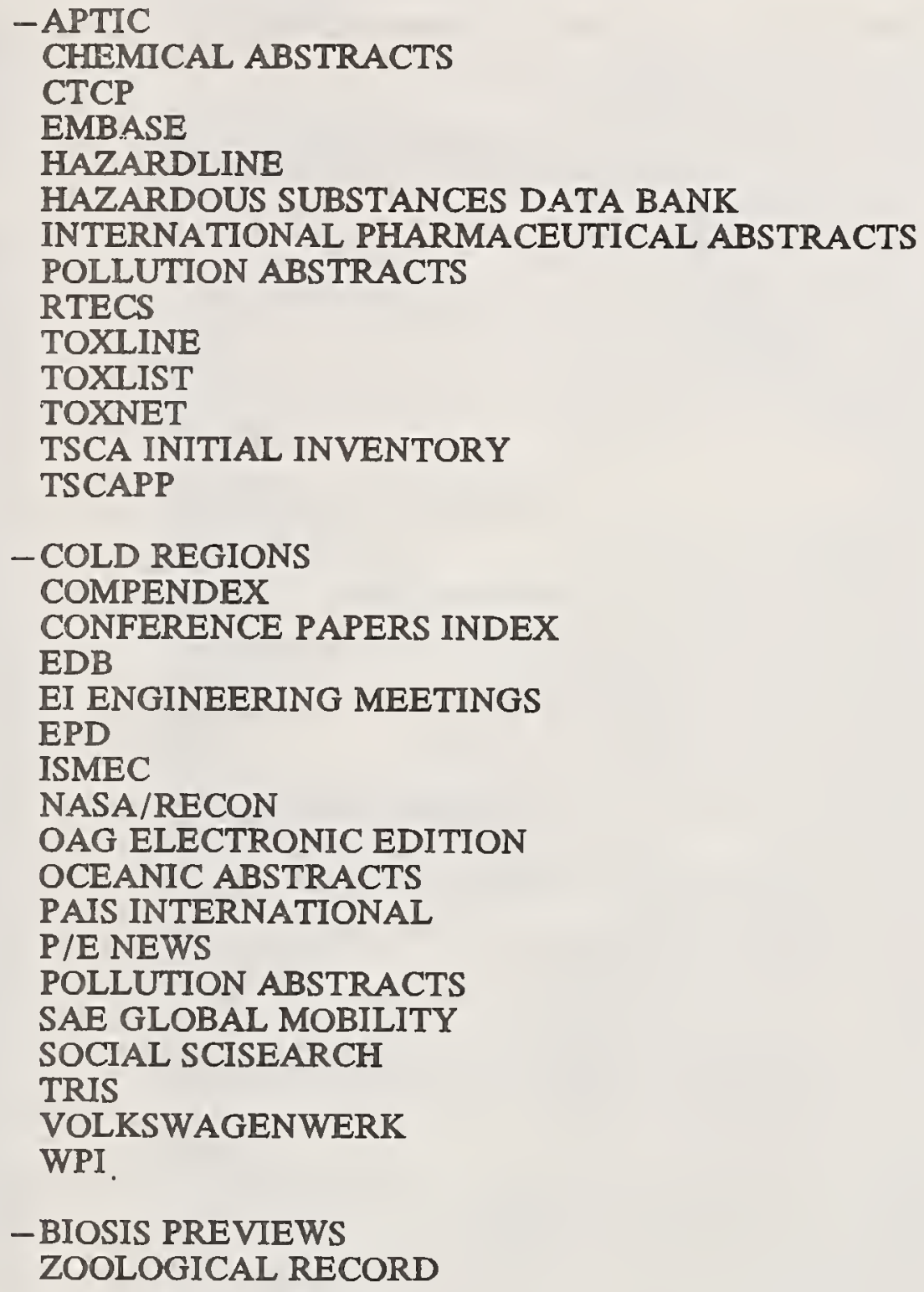


Abstract Bulletin of the Institute of Paper Chemistry Abstracted Business Information/Inform Abstracts in Biocommerce

Abstracts of Instructional and Research Materials

Abstracts of Instructional Materials in Vocational and Technical Education

Abstracts on Tropical Agriculture

Accountants' Index

Achema Handbook Pollution Control

Achema Yearbook

Agricultural On-Line Access

AGRINDEX

AGROW

AHL

AI Abstracts

Air Pollution Abstracts

Air Pollution Technical Information Center

American Banker

American Doctoral Dissertations

American Petroleum Institute Literature

American Petroleum Institute Patents

American Statistics Index

American Theological Library Association Religion

Animal Pharm

The Annual Book of ASTM Standards

Antarctic Bibliography

Aquatic Information Retrieval

Aquatic Sciences and Fisheries Abstracts

Architectural Periodicals Index

Architectural Books Catalogue

The Associated Press

Audiovisual Catalog On-Line

Automotive Abstracts

BHRA Fluid Engineering Abstracts

Bibliography and Index of Geology

Bibliography and Index of Geology Exclusive of

North America

Bibliography and Index of North American Geology

Bibliography of Agriculture

Bibliography of Bioethics

Bibliography of the History of Medicine

Bibliography of Thesis in Geology

Bibliography on Cold Regions

Biological Abstracts

Biomass Abstracts

BMFT Support Catalog

BNF Nonferrous Metals Abstracts

CA Chemical Name Dictionary

CAD/CAM Abstracts

California Union List of Periodicals

Cancer Literature

\author{
PAPERCHEM \\ ABI/INFORM \\ BIOCOMMERCE ABSTRACTS \\ AIM/ARM \\ AIM/ARM \\ TROPAG \\ ACCOUNTANTS \\ DETEQ \\ DEQUIP \\ AGRICOLA \\ AGRIS INTERNATIONAL \\ PJB PHARMACEUTICAL INDUSTRY NEWS \\ AMERICA: HISTORY AND LIFE \\ SUPERTECH \\ APTIC \\ APTIC \\ BANKER \\ DISSERTATION ABSTRACTS ONLINE \\ APILIT \\ APIPAT \\ ASI \\ RELIGION INDEX \\ PJB PHARMACEUTICAL INDUSTRY NEWS \\ STANDARDS SEARCH \\ COLD REGIONS \\ AQUIRE \\ ASFA \\ ARCHITECTURE DATABASE \\ ARCHITECTURE DATABASE \\ AP NEWS \\ AVLINE \\ SAE GLOBAL MOBILITY \\ FLUIDEX \\ GEOREF \\ GEOREF \\ GEOREF \\ AGRICOLA \\ BIOETHICS \\ HISTLINE \\ GEOREF \\ COLD REGIONS \\ BIOSIS PREVIEWS \\ BIOMASS \\ FORKAT \\ NONFERROUS METALS ABSTRACTS \\ CHEMNAME \\ SUPERTECH \\ CULP \\ CANCERLIT
}


Cancer Therapy Abstracts

Carbon-13 Nuclear Magnetic Resonance Spectral Search System

Carcinogenesis Abstracts

CASIA

CASR

Catalog On-Line

Catalogue of British Official Publications Not Published CDI

Center for Exceptional Children

Ceramic Abstracts

CHEM Sources USA

\section{CHEMCON/CHEM 7071}

Chemical Abstracts Chemical Name Directory

Chemical Abstracts Service Source Index

Chemical Carcinogenesis Research Information System

Chemical Dictionary On-Line

Chemical Evaluation Search and Retrieval System

Chemical Hazard Response Information System

Chemical Industry Notes

Chemicals Identified in Feral and Food Animals

Chemicals Identified in Human Biological Media

CIC's School Directory

\section{Clinica}

Clinical Protocols

Clinical Toxicology of Commercial Products

Commonwealth Agricultural Bureaux Abstracts

Comprehensive Dissertation Index

Compumath Citation Index

Computer and Control Abstracts

Computer-Readable Databases

Computerized Engineering Index

Congressional Information Service

Congressional Record Abstracts

Consumer Drug Digest

Corrosion Resistance Tables

CPI

Current Catalog

Current Index to Journals in Education

Current Index to Statistics

Current Law Index

Current Physics Index

Current Projects in Vocational Education

Current Research Information System

Defense RDT + E On-Line System

Defense Technical Information Center

Design Institute for Physical Property Data

Development Business

Dictionary of Organic Compounds

Dictionary of Organometallic Compounds

\section{CANCERIIT \\ CNMR}

CANCERLIT

CHEMICAL ABSTRACTS

CHEMICAL ACTIVITY STATUS REPORT

CATLINE

BRITISH OFFICIAL PUBLICATIONS

(NON HMSO)

DISSERTATION ABSTRACTS ONLINE

ECER

AMERICAN CERAMIC ABSTRACTS

CSCHEM

CSCORP

CHEMICAL ABSTRACTS

CHEMNAME

CASSI

CCRIS

CHEMLINE

CESARS

CHRIS

CIN

CHEMICAL EXPOSURE

CHEMICAL EXPOSURE

D\&B ELECTRONIC DIRECTORY OF EDUCATION

PJB PHARMACEUTICAL INDUSTRY NEWS

CLINPROT

CTCP

CAB ABSTRACTS

DISSERTATION ABSTRACTS ONLINE

COMPUTER AND MATHEMATICS SEARCH

INSPEC

DATABASE OF DATABASES

COMPENDEX

CIS

CRECORD

CONSUMER DRUG INFORMATION FULLTEXT

CORROSION

CONFERENCE PAPERS INDEX

CATLINE

ERIC

MATHSCI

LEGAL RESOURCE INDEX

SPIN

RESOURCES IN VOCATIONAL EDUCATION

CRIS/USDA

DROLS

DROLS

DIPPR

SCAN-A-BID

HEILBRON

HEILBRON 
Directory of Federal and State Business Assistance Directory of Industry Data Sources

Directory of Online Databases

Dissertation Abstracts International

Dissertation Index

DOE Energy Data Base

Drug Info/Alcohol Use-Abuse

Drug Literature Index

DTIC

Ecological Abstracts

Economic Titles and Abstracts

Educational Resources Information Center

Electric Power Industry Abstracts

Electrical and Electronic Abstracts

Electric Power Database

Energy Abstracts

Energy Abstracts for Policy Analysis

Energy Bibliography and Index

Energy Information Abstracts

Energy Research Abstracts

Engineering Index

Environment Abstracts

EPB

Exceptional Child Education Abstracts

Exerpta Medica

$\mathrm{F}+\mathrm{S}$ Indexes

Faculty Alert Bulletin

Fair Employment Practice Cases

FD

Federal Index

Federal Register Abstracts

FGI

FIND/SVP Reports and Studies Index

Foundation News

FSTA

\section{FTI}

Funk and Scott

Geographical Abstracts

Geological Abstracts Service

Geological Reference File

Geophysical Abstracts

German National Bibliography

German Patent Database

Government-Industry Data Exchange Program

Government Reports Announcements

GP-General Practitioner

GRA

Grant Information System

Health Planning and Administration

History of Medicine On-Line
FEDERAL AND STATE BUSINESS ASSISTANCE INDUSTRY DATA SOURCES

CUADRA DIRECTORY OF ONLINE DATABASES

DISSERTATION ABSTRACTS ONLINE

DISSERTATION ABSTRACTS ONLINE

EDB

DRUG

EMBASE

DROLS

GEOBASE

FOREIGN TRADE AND ECONOMIC

ABSTRACTS

ERIC

EPIA

INSPEC

EPD

ENERGYLINE

EDB

EBIB

ENERGYLINE

EDB

COMPENDEX

ENVIROLINE

ENVIRONMENTAL BIBLIOGRAPHY

ECER

EMBASE

PTS F +S INDEXES

GRANTS

LABORLAW

FOUNDATION DIRECTORY

PTS FEDERAL INDEX

FEDREG

FOUNDATION GRANTS INDEX

FINDEX REPORTS AND STUDIES

FOUNDATION GRANTS INDEX

FOOD SCIENCE AND TECHNOLOGY ABSTRACTS

FOREIGN TRADERS INDEX

PTS F + S INDEXES

GEOBASE

GEOBASE

GEOREF

GEOREF

BIBLIODATA

DEUTSCHE PATENT DATENBANK

GIDEP

NTIS

GENERAL PRACTITIONER

NTIS

GRANTS

HEALTH

HISTLINE 
Hospital Literature Index

HRIS Abstracts

ICO Library Monthly Entries

IFIS

Index Medicus

Index to Statistics and Probability

Inform

Information Bank

Information Service in Mechanical Engineering

Information System for Hazardous Organics in Water

Information Technology

Inforum

Infrared Search Systems

International Aerospace Abstracts

International Development Abstracts

International Labour Documentation

IPA

ISMEC Bulletin

Jane's Defence Weekly

Japan Patent Information Organization

Journal AWWA

Journal of the Association of Official Analytical Chemists

Keynote Reports

Labor Arbitration Reports

Labor Relations

Language and Language Behavior Abstracts

LC/Line

Leisure, Recreation and Tourism Abstracts

Libcon

Library and Information Science Abstracts

Library of Congress

Life Insurance Index

LLBA

\section{LRI}

Mass Spectral Search System

Mathematical Reviews

MEDECONOMICS

MEDLARS On-Line

Metals Abstracts/Alloys Index

MGA

MIMS Magazine

Mine Safety and Health Cases

Mineralogical Abstracts

Modern Language Association Bibliography

Monthly Catalog of U.S. Government Publications

MRIS Abstracts

Mutagenicity Database

NASA Tech Briefs

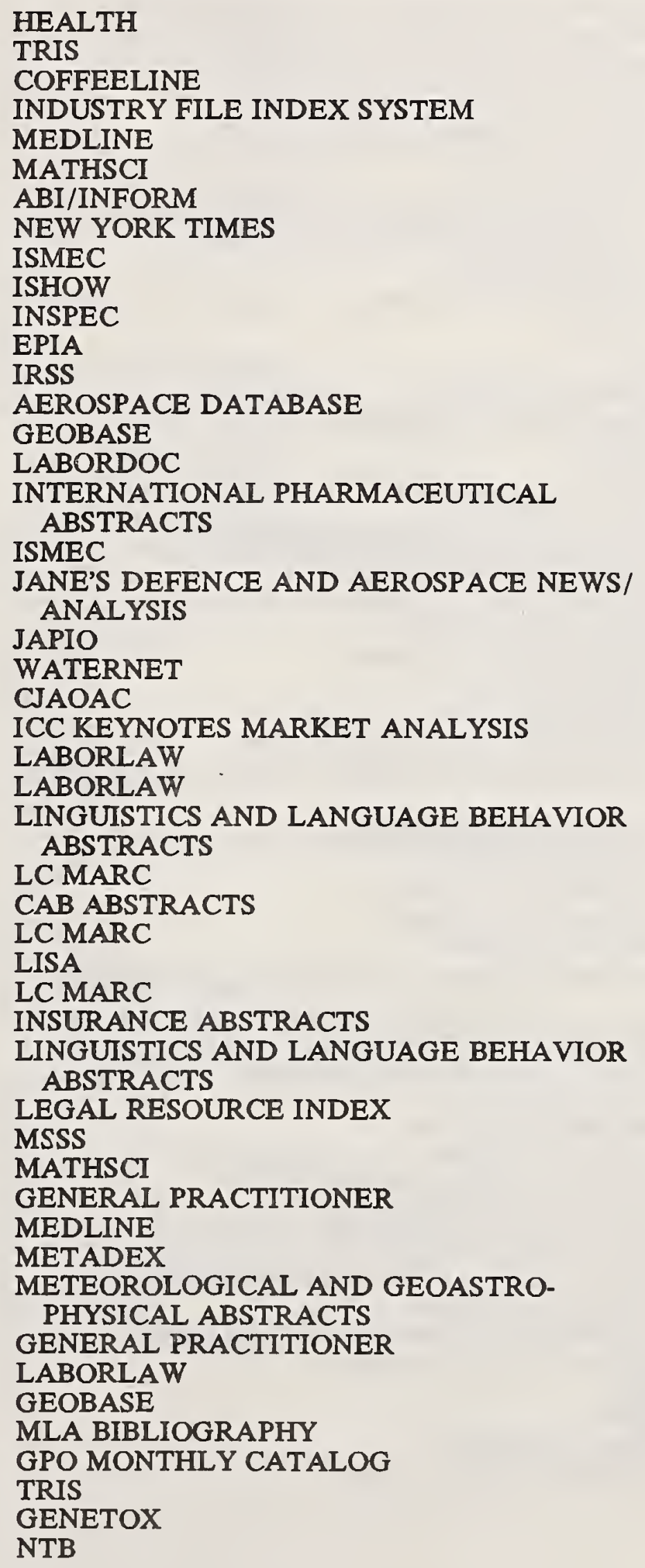


National Aeronautics and Space Administration

National Criminal Justice Reference Service

National Institute of Mental Health

National Rehabilitation Information Center

National Technical Information Service

Nederlands $A B C$ Voor Handel en Industrie

Nonferrous Alert

Nuclear Magnetic Resonance Literature System

Occupational Safety and Health Reporter

Oesterreich 2000

Oil and Hazardous Materials Technical Assistance Data System

PA

Packaging Abstracts

Paper and Board Abstracts

PATELL

PATS

Pesticide Manual

Peterson's Annual Guides/Graduate Study

Petroleum/Energy Business News Index

Pharmaceutical News Index

Photographic Abstracts

Physicians' Desk Reference

Physics Abstracts

Plant Toxicity Data

Polymer/Ceramics/Composites Alert

Predicasts Aerospace/Defense Markets and Technology

Predicasts Annual Reports

Predicasts Basebook

Predicasts F+S Indexes

Predicasts Federal Index

Predicasts Forecasts

Predicasts Marketing and Advertising Reference Service

Predicasts New Product Announcements

Predicasts Overview of Markets and Technology

Predicasts Promt

Predicasts 1 ime Series

Projects in Progress

Property and Liability Insurance Index

Psychological Abstracts

Public Affairs Information Service

Registry of Toxic Effects of Chemical Substances

Research in Education

Retrospective Machine Readable Cataloging

Review of Metal Literature

RILA

RIVE

Robomatix Reporter

The SAE Aerospace Index

\author{
NASA/RECON \\ NCJRS \\ NIMH \\ NARIC \\ NTIS \\ HOPPENSTEDT NETHERLANDS \\ MATERIALS/B \\ NMRLIT \\ LABORLAW \\ HOPPENSTEDT AUSTRIA \\ OHMTADS
}

\author{
PSYCHINFO \\ PIRA \\ PIRA \\ PSYCHINFO \\ PATDATA \\ GRADLINE \\ P/E NEWS \\ PNI \\ IMAGING ABSTRACTS \\ PDR \\ INSPEC \\ PHYTOTOX \\ MATERIALS/B
}

THE PESTICIDE DATABANK

PTS AEROSPACE/DEFENSE MARKETS AND TECHNOLOGY

PTS ANNUAL REPORTS

PTS FORECASTS

PTS F + S INDEXES

PTS FEDERAL INDEX

PTS FORECASTS

PTS MARKETING AND ADVERTISING

REFERENCE SERVICE

PTS NEW PRODUCT ANNOUNCEMENTS

PTS PROMT

PTS PROMT

PTS TIME SERIES

RESOURCES IN VOCATIONAL EDUCATION

INSURANCE ABSTRACTS

PSYCHINFO

PAIS

RTECS

ERIC

REMARC

METADEX

ART LITERATURE INTERNATIONAL

RESOURCES IN VOCATIONAL EDUCATION

SUPERTECH

STANDARDS SEARCH 
The SAE AMS Index of Aerospace Material Specifications The SAE Handbook

SAE Quarterly Abstracts

Safety Science Abstracts

Science Abstracts

Science Citation Index

Scientific and Technical Aerospace Reports

Scrip

Searchable Physics Information Notices

Selected Water Resources Abstracts

Serials On-Line

Smithsonian Science Information Exchange

Social Sciences Citation Index

Society of Automotive Engineers

Soft

Software Encyclopedia

\section{SPIF}

Sport and Recreation Index

State Department Bulletin

Steels Alert

Structure and Nomenclature Search System

SWRA

Technical Abstract Bulletin

Telecommunication Abstracts

Teleget Reporter Review

Toxic Substances Control Act Test Submissions

Toxic Substances Control Act (TSCA) Initial Inventory

Toxicology Information On-Line

Transportation Research Information Services

U.S. Patent Alert

U.S. Patent Master Classification File

U.S. Patent Official Gazette

USPSD

\section{WAA}

Wage and Hour Cases

Water Resources Abstracts

Weekly Compilation of Presidential Documents

World Patent Index

World Surface Coatings Abstracts

World Textile Abstracts

Worldcasts

WRC Information

WTA

Zentralblatt für Mathematik
STANDARDS SEARCH

STANDARDS SEARCH

SAE GLOBAL MOBILILTY

SAFETY

INSPEC

SCISEARCH

AEROSPACE DATABASE

PJB PHARMACEUTICAL INDUSTRY NEWS

SPIN

WRA

SERLINE

SSIE

SOCIAL SCISEARCH

SAE GLOBAL MOBILITY

ONLINE MICROCOMPUTER SOFTWARE GUIDE AND DIRECTORY

MICROCOMPUTER SOFTWARE AND

HARDWARE GUIDE

SCHOOL PRACTICES INFORMATION FILE

SPORT

WASHINGTON PRESSTEXT

MATERIALS/B

SANSS

WRA

DROLS

SUPERTECH

SUPERTECH

TSCATS

TSCA CHEMICAL SUBSTANCES INVENTORY

TOXLINE

TRIS

USPA

USCLASS

CLAIMS/PATENTS

UNITED STATES POLITICAL SCIENCE

DOCUMENTS

WORLD ALUMINUM ABSTRACTS

LABORLAW

WRA

WASHINGTON PRESSTEXT

WPI

SURFACE COATINGS ABSTRACTS

WORLD TEXTILES

PTS FORECASTS

AQUALINE

WORLD TEXTILES

MATH 

NBS.114A (REV. 2-8C)

U.S. DEPT. OF COMM.

BIBLIOGRAPHIC DATA

SHEET (See in structions)

1. PUBLICATION OR
REPORT NO.
NIST/SP-753

Publication Date

November 1988

4. TITLE AND SUBTITLE

Data Bases Available at the National Institute of Standards and Technology

Research Information Center

\section{AUTHOR(S)}

Diane Cunningham

6. PERFORMING ORGANIZATION (If joint or other than NBS, see instructions)

7. ContracUGrant No.

NATIONAL INSTITUTE OF STANDARDS AND TECHNOLOGY

(formorly NATIONAL BUREAU OF STANDARDS)

U.S. DEPARTMENT OF COMMERCE

GATHERSBURG, MD 20099

8. Type of Report \& Period Covered Final

9. SPONSORING ORGANIZATION NAME AND COMPLETE ADDRESS (Street, City, State, ZIP)

Same as item 6.

10. SUPPLEMENTARY NOTES

Supersedes NBSIR 87-3658 (July 1987)

Library of Congress Catalog Card Number: 88-600602

Document describes a computer program; SF-185, FIPS Software Summary, is attached.

11. ABSTRACT (A 200-word or less factual summary of most significant information. If document includes a significant bibliography or literature survey. mention it here)

Data bases available online at the National Institute of Standards and Technology (NIST) Research Information Center are listed by acronym and by full title. In addition, descriptions of the data bases, periods of coverage, producers, corresponding hard copy titles and principal sources and vendors are listed. A general subject index and a cross reference index are also supplied.

12. KEY WORDS (Six to twelve entries; alphabetical order: copltalize only proper names; and separate key words by semicolons bibliographic data bases; computerized data bases; information storage and retrieval systems; libraries, automation; machine-readable bibliographic data

\section{AVAILABILITY}

¿X Unlimited

$\square$ For Official Distribution. Do Not Release to NTIS

[X] Order From Superintendent of Documents, U.S. Government Printing Office, Washington, D.C. 20402.

X Order From National Technical Information Service (NTIS), Springfield, VA. 22161
14. NO. OF

PRINTED PAGES

114

15. Price 




\section{Technical Publications}

\section{Periodical}

Journal of Research of the National Institute of Standards and Technology-Reports NIST research and development in those disciplines of the physical and engineering sciences in which the Institute is active. These include physics, chemistry, engineering, mathematics, and computer sciences. Papers cover a broad range of subjects, with major emphasis on measurement methodology and the basic technology underlying standardization. Also included from time to time are survey articles on topics closely related to the Institute's technical and scientific programs. Issued six times a year.

\section{Nonperiodicals}

Monographs-Major contributions to the technical literature on various subjects related to the Institute's scientific and technical activities.

Handbooks-Recommended codes of engineering and industrial practice (including safety codes) developed in cooperation with interested industries, professional organizations, and regulatory bodies. Special Publications-Include proceedings of conferences sponsored by NIST, NIST annual reports, and other special publications appropriate to this grouping such as wall charts, pocket cards, and bibliographies.

Applied Mathematics Series-Mathematical tables, manuals, and studies of special interest to physicists, engineers, chemists, biologists, mathematicians, computer programmers, and others engaged in scientific and technical work.

National Standard Reference Data Series-Provides quantitative data on the physical and chemical properties of materials, compiled from the world's literature and critically evaluated. Developed under a worldwide program coordinated by NIST under the authority of the National Standard Data Act (Public Law 90-396). NOTE: The Journal of Physical and Chemical Reference Data (JPCRD) is published quarterly for NIST by the American Chemical Society (ACS) and the American Institute of Physics (AIP). Subscriptions, reprints, and supplements are available from ACS, 1155 Sixteenth St., NW., Washington, DC 20056.

Building Science Series-Disseminates technical information developed at the Institute on building materials, components, systems, and whole structures. The series presents research results, test methods, and performance criteria related to the structural and environmental functions and the durability and safety characteristics of building elements and systems.

Technical Notes-Studies or reports which are complete in themselves but restrictive in their treatment of a subject. Analogous to monographs but not so comprehensive in scope or definitive in treatment of the subject area. Often serve as a vehicle for final reports of work performed at NIST under the sponsorship of other government agencies.

Voluntary Product Standards-Developed under procedures published by the Department of Commerce in Part 10, Title 15, of the Code of Federal Regulations. The standards establish nationally recognized requirements for products, and provide all concerned interests with a basis for common understanding of the characteristics of the products. NIST administers this program as a supplement to the activities of the private sector standardizing organizations.

Consumer Information Series-Practical information, based on NIST research and experience, covering areas of interest to the consumer. Easily understandable language and illustrations provide useful background knowledge for shopping in today's technological marketplace.

Order the above NIST publications from: Superintendent of Documents, Government Printing Office, Washington, DC 20402.

Order the following NIST publications-FIPS and NISTIRs-from the National Technical Information Service, Springfield, VA 22161.

Federal Information Processing Standards Publications (FIPS PUB)-Publications in this series collectively constitute the Federal Information Processing Standards Register. The Register serves as the official source of information in the Federal Government regarding standards issued by NIST pursuant to the Federal Property and Administrative Services Act of 1949 as amended, Public Law 89-306 (79 Stat. 1127), and as implemented by Executive Order 11717 (38 FR 12315, dated May 11, 1973) and Part 6 of Title 15 CFR (Code of Federal Regulations).

NIST Interagency Reports (NISTIR)-A special series of interim or final reports on work performed by NIST for outside sponsors (both government and non-government). In general, initial distribution is handled by the sponsor; public distribution is by the National Technical Information Service, Springfield, VA 22161, in paper copy or microfiche form. 
U.S. Department of Commerce

National Institute of Standards and Technology

(formerly National Bureau of Standards)

Gaithersburg, MD 20899

Official Business

Penalty for Private Use $\$ 300$

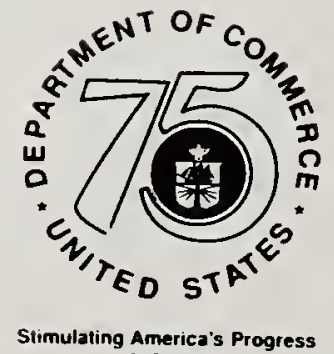

